4

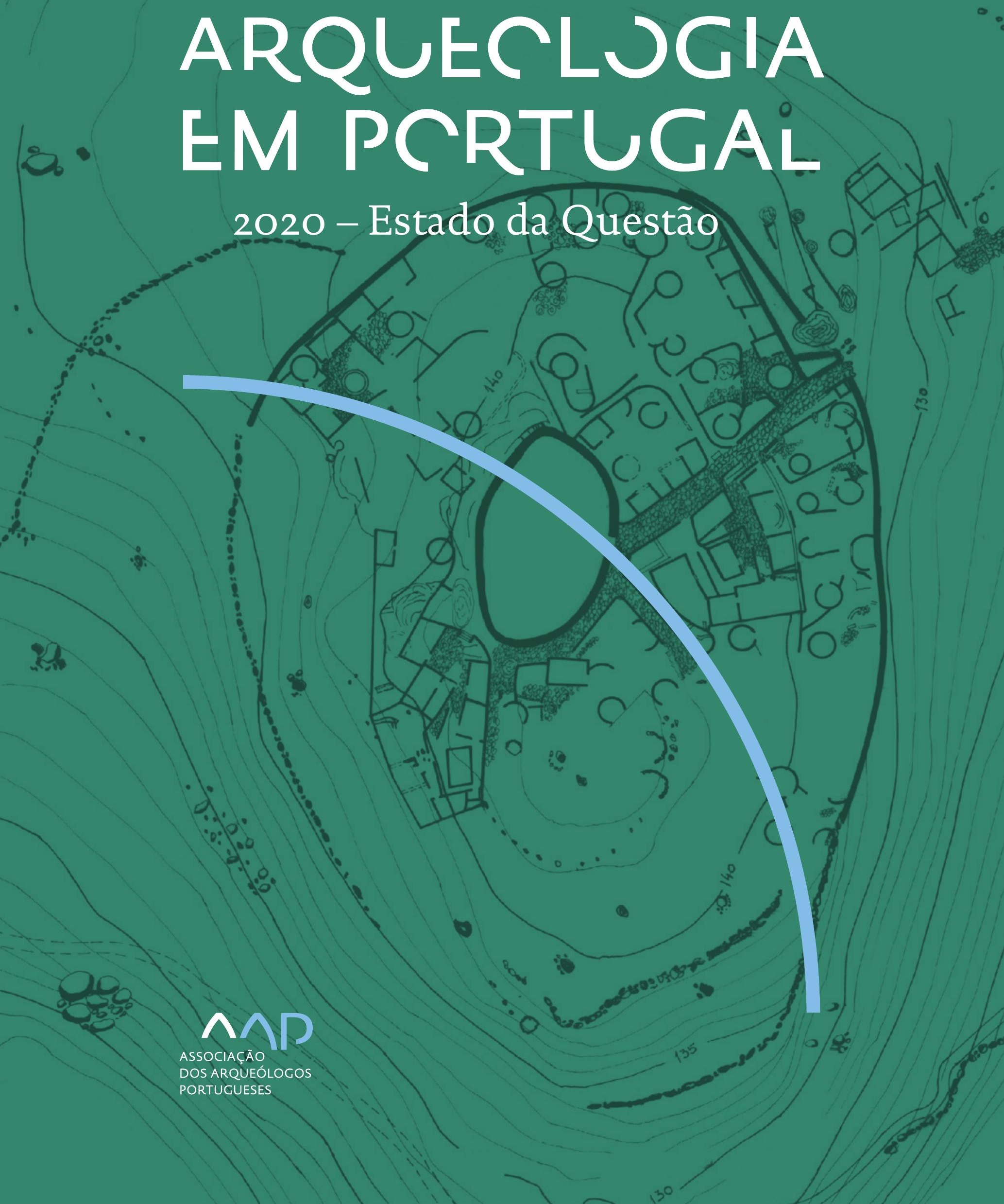


Coordenação editorial: José Morais Arnaud, César Neves e Andrea Martins Design gráfico: Flatland Design

AAP - ISBN: 978-972-9451-89-8

CITCEM - ISBN: 978-989-8970-25-1

Associação dos Arqueólogos Portugueses e CITCEM

Lisboa, 2020

O conteúdo dos artigos é da inteira responsabilidade dos autores. Sendo assim a Associação dos Arqueólogos Portugueses declina qualquer responsabilidade por eventuais equívocos ou questões de ordem ética e legal.

Desenho de capa:

Planta do castro de Monte Mozinho (Museu Municipal de Penafiel).

\section{$\hat{\wedge} \mathrm{P}$}

DOS ARQUEÓLOGOS PORTUGUESES

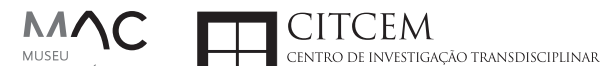
MUSEU
ARQUELLÓGICO
DO CARMO
U.PORTO

FLUP FACULDADE DE LETRAS
UNIVERSIDADE DO PORTO

Apoio

EC para a Ciência 


\section{Índice}

15 Prefácio

José Morais Arnaud

\section{Historiografia e Teoria}

17 Território, comunidade, memória e emoção: a contribuição da história da arqueologia (algumas primeiras e breves reflexões)

Ana Cristina Martins

25 Como descolonizar a arqueologia portuguesa?

Rui Gomes Coelho

41 Arqueologia e Modernidade: uma revisitação pessoal e breve de alguns aspetos da obra homónima de Julian Thomas de 2004

Vítor Oliveira Jorge

57 Dados para a História das Mulheres na Arqueologia portuguesa, dos finais do século XIX aos inícios do século XX: números, nomes e tabelas

Filipa Dimas / Mariana Diniz

73 Retractos da arqueologia portuguesa na imprensa: (in)visibilidades no feminino

Catarina Costeira / Elsa Luís

85 Arqueologia e Arqueólogos no Norte de Portugal Jacinta Bugalhão

101 Vieira Guimarães (1864-1939) e a arqueologia em Tomar: uma abordagem sobre o território e as gentes

João Amendoeira Peixoto / Ana Cristina Martins

115 Os memoráveis? A arqueologia algarvia na imprensa nacional e regional na presente centúria (2001-2019): características, visões do(s) passado(s) e a arqueologia

enquanto marca

Frederico Agosto / João Silva

129 A Evolução da Arqueologia Urbana e a Valorização Patrimonial no Barlavento Algarvio: Os casos de Portimão e Silves

Artur Mateus / Diogo Varandas / Rafael Boavida

\section{Gestão, Valorização e Salvaguarda do Património}

145 O Caderno Reivindicativo e as condições de trabalho em Arqueologia Miguel Rocha / Liliana Matias Carvalho / Regis Barbosa / Mauro Correia / Sara Simões / Jacinta Bugalhão / Sara Brito / Liliana Veríssimo Carvalho / Richard Peace / Pedro Peça / Cézer Santos

155 Os Estudos de Impacte Patrimonial como elemento para uma estratégia sustentável de minimização de impactes no âmbito de reconversões agrícolas Tiago do Pereiro

165 Salvaguarda de Património arqueológico em operações florestais: gestão e sensibilização Filipa Bragança / Gertrudes Zambujo / Sandra Lourenço / Belém Paiva / Carlos Banha / Frederico Tatá Regala / Helena Moura / Jacinta Bugalhão / João Marques / José Correia / Pedro Faria / Samuel Melro

179 Os valores do Património: uma investigação sobre os Sítios Pré-históricos de Arte Rupestre do Vale do Rio Côa e de Siega Verde José Paulo Francisco 
189 Conjugando recursos arqueológicos e naturais para potenciar as visitas ao Geoparque Litoral de Viana do Castelo (Noroeste de Portugal)

Hugo A. Sampaio / Ana M.S. Bettencourt / Susana Marinho / Ricardo Carvalhido

203 Áreas de Potencial Arqueológico na Região do Médio Tejo: Modelo Espacial Preditivo Rita Ferreira Anastácio / Ana Filipa Martins / Luiz Oosterbeek

223 Património Arqueológico e Gestão Territorial: O contributo da Arqueologia para a revisão do PDM de Avis

Ana Cristina Ribeiro

237 A coleção arqueológica do extinto Museu Municipal do Porto - Origens, Percursos e Estudos

Sónia Couto

251 Valpaços - uma nova carta arqueológica

Pedro Pereira / Maria de Fátima Casares Machado

263 Arqueologia na Cidade de Peniche

Adriano Constantino / Luís Rendeiro

273 Arqueologia Urbana: a cidade de Lagos como caso de Estudo Cátia Neto

285 Estratégias de promoção do património cultural subaquático nos Açores. O caso da ilha do Faial

José Luís Neto / José Bettencourt / Luís Borges / Pedro Parreira

297 Carta Arqueológica da Cidade Velha: Uma primeira abordagem

Jaylson Monteiro / Nireide Tavares / Sara da Veiga / Claudino Ramos / Edson Brito /

Carlos Carvalho / Francisco Moreira / Adalberto Tavares

311 Antropologia Virtual: novas metodologias para a análise morfológica e funcional Ricardo Miguel Godinho / Célia Gonçalves

\section{Didáctica da Arqueologia}

327 Como os projetos de Arqueologia podem contribuir para uma comunidade culturalmente mais consciente Alexandra Figueiredo / Claúdio Monteiro / Adolfo Silveira / Ricardo Lopes

337 Educação Patrimonial - Um cidadão esclarecido é um cidadão ativo! Ana Paula Almeida

351 A aproximação da Arqueologia à sala de aula: um caso de estudo no $3^{\circ}$ ciclo do Ensino Básico Luís Serrão Gil

363 Arqueologia 3.o - Pensar e comunicar a Arqueologia para um futuro sustentável Mónica Rolo

377 “Conversa de Arqueólogos" - Divulgar a Arqueologia em tempos de Pandemia Diogo Teixeira Dias

389 Escola Profissional de Arqueologia: desafios e oportunidades Susana Nunes / Dulcineia Pinto / Júlia Silva / Ana Mascarenhas

399 Os Museus de Arqueologia e os Jovens: a oferta educativa para o público adolescente Beatriz Correia Barata / Leonor Medeiros

411 O museu universitário como mediador entre a ciência e a sociedade: o exemplo da secção de arqueologia no Museu de História Natural e da Ciência da Universidade do Porto (MHNC-UP)

Rita Gaspar 
421 Museu de Lanifícios: Real Fábrica de Panos. Atividades no âmbito da Arqueologia Beatriz Correia Barata / Rita Salvado

427 Arqueologia Pública e o caso da localidade da Mata (Torres Novas) Cláudia Manso / Ana Rita Ferreira / Cristiana Ferreira / Vanessa Cardoso Antunes

431 Do sítio arqueológico ao museu: um percurso (também) didático Lídia Fernandes

447 Estão todos convidados para a Festa! E para dançar também... O projecto do Serviço Educativo do Museu Arqueológico do Carmo na $5^{\underline{a}}$ Edição da Festa da Arqueologia Rita Pires dos Santos

459 O “Clã de Carenque”, um projeto didático de arqueologia Eduardo Gonzalez Rocha

469 Mediação cultural: peixe que puxa carroça nas Ruínas Romanas de Troia Inês Vaz Pinto / Ana Patrícia Magalhães / Patrícia Brum / Filipa Santos

481 Didática Arqueológica, experiências do Projeto Mértola Vila Museu Maria de Fátima Palma / Clara Rodrigues / Susana Gómez / Lígia Rafael

\section{Arte Rupestre}

497 Os inventários de arte rupestre em Portugal Mila Simões de Abreu

513 O projeto FIRST-ART - conservação, documentação e gestão das primeiras manifestações de arte rupestre no Sudoeste da Península Ibérica: as grutas do Escoural e Maltravieso Sara Garcês / Hipólito Collado / José Julio García Arranz / Luiz Oosterbeek / António Carlos Silva / Pierluigi Rosina / Hugo Gomes / Anabela Borralheiro Pereira / George Nash / Esmeralda Gomes / Nelson Almeida / Carlos Carpetudo

523 Trabalhos de documentação de arte paleolítica realizados no âmbito do projeto PalæoCôa André Tomás Santos / António Fernando Barbosa / Luís Luís / Marcelo Silvestre / Thierry Aubry

537 Imagens fantasmagóricas, silhuetas elusivas: as figuras humanas na arte do Paleolítico Superior da região do Côa Mário Reis

$55^{1}$ Os motivos zoomórficos representados nas placas de tear de Vila Nova de São Pedro (Azambuja, Portugal) Andrea Martins / César Neves / José M. Arnaud / Mariana Diniz

571 Arte Rupestre do Monte de Góios (Lanhelas, Caminha). Síntese dos resultados dos trabalhos efectuados em 2007-2009 Mário Varela Gomes

599 Gravuras rupestres de barquiformes no Monte de S. Romão, Guimarães, Noroeste de Portugal Daniela Cardoso

613 Círculos segmentados gravados na Bacia do Rio Lima (Noroeste de Portugal): contributos para o seu estudo Diogo Marinho / Ana M.S. Bettencourt / Hugo Aluai Sampaio

631 Equídeos gravados no curso inferior do Rio Mouro, Monção (NW Portugal). Análise preliminar Coutinho, L.M. / Bettencourt, A.M.S / Sampaio, Hugo A.S

645 Paletas na Arte Rupestre do Noroeste de Portugal. Inventário preliminar Bruna Sousa Afonso / Ana M. S. Bettencourt / Hugo A. Sampaio 


\section{Pré-História}

661 O projeto Miño/Minho: balanço de quatro anos de trabalhos arqueológicos Sérgio Monteiro-Rodrigues / João Pedro Cunha-Ribeiro / Eduardo Méndez-Quintas / Carlos Ferreira / Pedro Xavier / José Meireles / Alberto Gomes / Manuel Santonja / Alfredo Pérez-González

677 A ocupação paleolítica da margem esquerda do Baixo Minho: a indústria lítica do sítio de Pedreiras 2 (Monção, Portugal) e a sua integração no contexto regional Carlos Ferreira / João Pedro Cunha-Ribeiro / Sérgio Monteiro-Rodrigues / Eduardo Méndez-Quintas / Pedro Xavier / José Meireles / Alberto Gomes / Manuel Santonja / Alfredo Pérez-González

693 O sítio acheulense do Plistocénico médio da Gruta da Aroeira Joan Daura / Montserrat Sanz / Filipa Rodrigues / Pedro Souto / João Zilhão

703 As sociedades neandertais no Barlavento algarvio: modelos preditivos com recurso aos SIG

Daniela Maio

715 A utilização de quartzo durante o Paleolítico Superior no território dos vales dos rios Vouga e Côa

Cristina Gameiro / Thierry Aubry / Bárbara Costa / Sérgio Gomes / Luís Luís / Carmen Manzano / André Tomás Santos

733 Uma perspetiva diacrónica da ocupação do concheiro do Cabeço da Amoreira (Muge, Portugal) a partir da tecnologia lítica Joana Belmiro / João Cascalheira / Célia Gonçalves

745 Novos dados sobre a Pré-história Antiga no concelho de Palmela. A intervenção arqueológica no sítio do Poceirão I

Michelle Teixeira Santos

757 Problemas em torno de Datas Absolutas Pré-Históricas no Norte do Alentejo Jorge de Oliveira

771 Povoamento pré-histórico nas áreas montanhosas do NO de Portugal: o Abrigo 1 de Vale de Cerdeira Pedro Xavier / José Meireles / Carlos Alves

783 Apreciação do povoamento do Neolítico Inicial na Baixa Bacia do Douro. A Lavra I (Serra da Aboboreira) como caso de estudo Maria de Jesus Sanches

797 O Processo de Neolitização na Plataforma do Mondego: os dados do Sector C do Outeiro dos Castelos de Beijós (Carregal do Sal)

João Carlos de Senna-Martinez / José Manuel Quintã Ventura / Andreia Carvalho / Cíntia Maurício

823 Novos trabalhos na Lapa da Bugalheira (Almonda, Torres Novas) Filipa Rodrigues / Pedro Souto / Artur Ferreira / Alexandre Varanda / Luís Gomes / Helena Gomes / João Zilhão

837 A pedra polida e afeiçoada do sítio do Neolítico médio da Moita do Ourives (Benavente, Portugal)

César Neves

857 Casal do Outeiro (Encarnação, Mafra): novos contributos para o conhecimento do povoamento do Neolítico final na Península de Lisboa.

Cátia Delicado / Carlos Maneira e Costa / Marta Miranda / Ana Catarina Sousa

873 Stresse infantil, morbilidade e mortalidade no sítio arqueológico do Neolítico Final/ Calcolítico ( $4^{\circ}$ e $3^{\circ}$ milénio a.C.) do Monte do Carrascal 2 (Ferreira do Alentejo, Beja) Liliana Matias de Carvalho / Sofia N. Wasterlain 
885 Come together: O Conjunto Megalítico das Motas (Monção, Viana do Castelo) e as expressões Campaniformes do Alto Minho Ana Catarina Basílio / Rui Ramos

899 Trabalhos arqueológicos no sítio Calcolítico da Pedreira do Poio Carla Magalhães / João Muralha / Mário Reis / António Batarda Fernandes

913 O sítio arqueológico de Castanheiro do Vento. Da arquitectura do sítio à arquitectura de um território João Muralha Cardoso

925 Estudo zooarqueológico das faunas do Calcolítico final de Vila Nova de São Pedro (Azambuja, Portugal): Campanhas de 2017 e 2018 Cleia Detry / Ana Catarina Francisco / Mariana Diniz / Andrea Martins / César Neves / José Morais Arnaud

943 As faunas depositadas no Museu Arqueológico do Carmo provenientes de Vila Nova de São Pedro (Azambuja): as campanhas de 1937 a 1967 Ana Catarina Francisco / Cleia Detry / César Neves / Andrea Martins / Mariana Diniz / José Morais Arnaud

959 Análise funcional de material lítico em sílex do castro de Vila Nova de S. Pedro (Azambuja, Portugal): uma primeira abordagem Rafael Lima

971 O recinto da Folha do Ouro 1 (Serpa) no contexto dos recintos de fossos calcolíticos alentejanos

António Carlos Valera / Tiago do Pereiro / Pedro Valério / António M. Monge Soares

\section{Proto-História}

987 Produção de sal marinho na Idade do Bronze do noroeste Português. Alguns dados para uma reflexão

Ana M. S. Bettencourt / Sara Luz / Nuno Oliveira / Pedro P. Simões / Maria Isabel C. Alves / Emílio Abad-Vidal

1001 A estátua-menir do Pedrão ou de São Bartolomeu do Mar (Esposende, noroeste de Portugal) no contexto arqueológico da fachada costeira de entre os rios Neiva e Cávado Ana M. S. Bettencourt / Manuel Santos-Estévez / Pedro Pimenta Simões / Luís Gonçalves

1015 O Castro do Muro (Vandoma/Baltar, Paredes) - notas para uma biografia de ocupação da Idade do Bronze à Idade Média

Maria Antónia D. Silva / Ana M. S. Bettencourt / António Manuel S. P. Silva / Natália Félix

1031 Do Bronze Final à Idade Média - continuidades e hiatos na ocupação de Povoados em Oliveira de Azeméis João Tiago Tavares / Adriaan de Man

1041 As faunas do final da Idade do Bronze no Sul de Portugal: leituras desde o Outeiro do Circo (Beja)

Nelson J. Almeida / Íris Dias / Cleia Detry / Eduardo Porfírio / Miguel Serra

1055 A Espada do Monte das Oliveiras (Serpa) - uma arma do Bronze Pleno do Sudoeste Rui M. G. Monge Soares / Pedro Valério / Mariana Nabais / António M. Monge Soares

1065 São Julião da Branca (Albergaria-a-Velha) - Investigação e valorização de um povoado do Bronze Final

António Manuel S. P. Silva / Paulo A. P. Lemos / Sara Almeida e Silva / Edite Martins de Sá

1083 Do castro de S. João ao Mosteiro de Santa Clara: notícia de uma intervenção arqueológica, em Vila do Conde Rui Pinheiro 
1095 O castro de Ovil (Espinho), um quarto de século de investigação - resultados e questões em aberto

Jorge Fernando Salvador / António Manuel S. P. Silva

1111 O Castro de Salreu (Estarreja), um povoado proto-histórico no litoral do Entre Douro e Vouga

Sara Almeida e Silva / António Manuel S. P. Silva / Paulo A. P. Lemos / Edite Martins de Sá

1127 Castro de Nossa Senhora das Necessidades (Sernancelhe): uma primeira análise artefactual Telma Susana O. Ribeiro

${ }_{1141}$ A cividade de Bagunte. O estado atual da investigação Pedro Brochado de Almeida

1153 Zoomorfos na cerâmica da Idade do Ferro no NW Peninsular: inventário, cronologias e significado Nuno Oliveira / Cristina Seoane

1163 Vasos gregos em Portugal: diferentes maneiras de contar a história do intercâmbio cultural na Idade do Ferro

Daniela Ferreira

1175 Os exotica da necrópole da Idade do Ferro do Olival do Senhor dos Mártires (Alcácer do Sal) no seu contexto regional

Francisco B. Gomes

\section{Antiguidade Clássica e Tardia}

1191 O uso de madeira como combustível no sítio da Quinta de Crestelos (Baixo Sabor): da Idade do Ferro à Romanização Filipe Vaz / João Tereso / Sérgio Simões Pereira / José Sastre / Javier Larrazabal Galarza / Susana Cosme / José António Pereira / Israel Espi

1207 Cultivos de Época Romana no Baixo Sabor: continuidade em tempos de mudança? João Pedro Tereso / Sérgio Simões Pereira / Filipe Santos / Luís Seabra / Filipe Vaz

1221 A casa romana na Hispânia: aplicação dos modelos itálicos nas províncias ibéricas Fernanda Magalhães / Diego Machado / Manuela Martins

1235 As pinturas murais romanas da Rua General Sousa Machado, n. ${ }^{5}$ 1, Chaves José Carvalho

1243 Trás do Castelo (Vale de Mir, Pegarinhos, Alijó) - Uma exploração agrícola romana do Douro

Tony Silvino / Pedro Pereira

1255 A sequência de ocupação no quadrante sudeste de Bracara Augusta: as transformações de uma unidade doméstica Lara Fernandes / Manuela Martins

1263 Os Mosaicos com decoração geométrica e geométrico-vegetalista dos sítios arqueológicos da área do Conuentus Bracaraugustanus. Novas abordagens quanto à conservação, restauro, decoração e datação Maria de Fátima Abraços / Licínia Wrench

1277 “Casa Romana” do Castro de São Domingos (Cristelos, Lousada): Escavação, Estudo e Musealização Paulo André de P. Lemos

1291 A arqueobotânica no Castro de Guifões (Matosinhos, Noroeste de Portugal): O primeiro estudo carpológico

Luís Seabra / Andreia Arezes / Catarina Magalhães / José Varela / João Pedro Tereso 
1305 Um Horreum Augustano na Foz do Douro (Monte do Castelo de Gaia, Vila Nova de Gaia) Rui Ramos

1311 Ponderais romanos na Lusitânia: padrões, formas, materiais e contextos de utilização Diego Barrios Rodríguez

1323 Um almofariz centro-itálico na foz do Mondego

Marco Penajoia

1335 Estruturas romanas de Carnide - Lisboa Luísa Batalha / Mário Monteiro / Guilherme Cardoso

1347 O contexto funerário do sector da "necrópole NO" da Rua das Portas de S. Antão (Lisboa): o espaço, os artefactos, os indivíduos e a sua interconectividade na interpretação do passado Sílvia Loja, José Carlos Quaresma, Nelson Cabaço, Marina Lourenço, Sílvia Casimiro, Rodrigo Banha da Silva, Francisca Alves-Cardoso

${ }_{1361}$ Povoamento em época Romana na Amadora - resultados de um projeto pluridisciplinar Gisela Encarnação / Vanessa Dias

1371 A Arquitectura Residencial em Mirobriga (Santiago do Cacém): contributo a partir de um estudo de caso Filipe Sousa / Catarina Felício

${ }_{1385}$ O fim do ciclo. Saneamento e gestão de resíduos nos edifícios termais de Mirobriga (Santiago do Cacém)

Catarina Felício / Filipe Sousa

1399 Balsa, Topografia e Urbanismo de uma Cidade Portuária Vítor Silva Dias / João Pedro Bernardes / Celso Candeias / Cristina Tété Garcia

1413 No Largo das Mouras Velhas em Faro (2017): novas evidências da necrópole norte de Ossonoba e da sua ocupação medieval Ricardo Costeira da Silva / Paulo Botelho / Fernando Santos / Liliana Nunes

1429 Instrumentos de pesca recuperados numa fábrica de salga em Ossonoba (Faro) Inês Rasteiro / Ricardo Costeira da Silva / Paulo Botelho

1439 A Necrópole Romana do Eirô, Duas Igrejas (Penafiel): intervenção arqueológica de 2016 Laura Sousa / Teresa Soeiro

1457 Ritual, descarte ou afetividade? A presença de Canis lupus familiaris na Necrópole Noroeste de Olisipo (Lisboa)

Beatriz Calapez Santos / Sofia Simões Pereira / Rodrigo Banha da Silva / Sílvia Casimiro / Cleia Detry / Francisca Alves Cardoso

1467 Dinâmicas económicas em Bracara na Antiguidade Tardia Diego Machado / Manuela Martins / Fernanda Magalhães / Natália Botica

1479 Cerâmicas e Vidros da Antiguidade Tardia do Edifício sob a Igreja do Bom Jesus (Vila Nova de Gaia) Joaquim Filipe Ramos

1493 Novos contributos para a topografia histórica de Mértola no período romano e na Antiguidade Tardia Virgílio Lopes

\section{8. Época Medieval}

1511 Cerâmicas islâmicas no Garb setentrional "português": algumas evidências e incógnitas Constança dos Santos / Helena Catarino / Susana Gómez / Maria José Gonçalves / Isabel Inácio / Gonçalo Lopes / Jacinta Bugalhão / Sandra Cavaco / Jaquelina Covaneiro / Isabel Cristina Fernandes / Ana Sofia Gomes 
1525 Contributo para o conhecimento da cosmética islâmica, em Silves, durante a Idade Média Rosa Varela Gomes

1537 Yábura e o seu território - uma análise histórico-arqueológica de Évora entre os séculos VIII-XII José Rui Santos

1547 A encosta sul do Castelo de Palmela - resultados preliminares da escavação arqueológica Luís Filipe Pereira / Michelle Teixeira Santos

1559 A igreja de São Lourenço (Mouraria, Lisboa): um conjunto de silos e de cerâmica medieval islâmica

Andreia Filipa Moreira Rodrigues

1571 O registo material de movimentações populacionais no Médio Tejo, durante os séculos XII-XIII. Dois casos de "sunken featured buildings", nos concelhos de Cartaxo e Torres Novas Marco Liberato / Helena Santos / Nuno Santos

1585 O nordeste transmontano nos alvores da Idade média. Notas para reflexão Ana Maria da Costa Oliveira

1601 Sepulturas escavadas na rocha do Norte de Portugal e do Vale do Douro: primeiros resultados do Projecto SER-NPVD

Mário Jorge Barroca / César Guedes / Andreia Arezes / Ana Maria Oliveira

1619 "Portucalem Castrum Novum" entre o Mediterrâneo e o Atlântico: o estudo dos materiais cerâmicos alto-medievais do arqueossítio da rua de D. Hugo, nํ. 5 (Porto) João Luís Veloso

1627 A Alta Idade Média na fronteira de Lafões: notas preliminares sobre a Arqueologia no Concelho de Vouzela

Manuel Luís Real / Catarina Tente

1641 Um conjunto cerâmico medieval fora de portas: um breve testemunho aveirense Susana Temudo

${ }_{1651}$ Os Lóios do Porto: uma perspetiva integrada no panorama funerário da Baixa Idade Média à Época Moderna em meios urbanos em Portugal

Ana Lema Seabra

1659 O Caminho Português Interior de Santiago como eixo viário na Idade Média Pedro Azevedo

1665 Morfologia Urbana: Um exercício em torno do Castelo de Ourém André Donas-Botto / Jaqueline Pereira

1677 Intervenção arqueológica na Rua Marquês de Pombal/Largo do Espírito Santo (Bucelas, Loures)

Florbela Estêvão / Nathalie Antunes-Ferreira / Dário Ramos Neves / Inês Lisboa

1691 O Cemitério Medieval do Poço do Borratém e a espacialidade funerária na cidade de Lisboa Inês Belém / Vanessa Filipe / Vasco Noronha Vieira / Sónia Ferro / Rodrigo Banha da Silva

1705 Um Espaço Funerário Conventual do séc. XV em Lisboa: o caso do Convento de São Domingos da Cidade Sérgio Pedroso / Sílvia Casimiro / Rodrigo Banha da Silva / Francisca Alves Cardoso

\section{9. Época Moderna e Contemporânea}

1721 Arqueologia Moderna em Portugal: algumas reflexões críticas em torno da quantificação de conjuntos cerâmicos e suas inferências históricas e antropológicas Rodrigo Banha da Silva / André Bargão / Sara da Cruz Ferreira

1733 Faianças de dois contextos entre os finais do século XVI e XVIII do Palácio dos Condes de Penafiel, Lisboa

Martim Lopes / Tomás Mesquita 
1747 Um perfil de consumo do século XVIII na foz do Tejo: O caso do Mercado da Ribeira, Lisboa Sara da Cruz Ferreira / Rodrigo Banha da Silva / André Bargão

1761 Os Cachimbos dos Séculos XVII e XVIII do Palácio Mesquitela e Convento dos Inglesinhos (Lisboa)

Inês Simão / Marina Pinto / João Pimenta / Sara da Cruz Ferreira / André Bargão / Rodrigo Banha da Silva

1775 "Tomar os fumos da erua que chamão em Portugal erua sancta». Estudo de Cachimbos provenientes da Rua do Terreiro do Trigo, Lisboa

Miguel Martins de Sousa / José Pedro Henriques / Vanessa Galiza Filipe

1787 Cachimbos de Barro Caulínitico da Sé da Cidade Velha (República de Cabo Verde)

Rodrigo Banha da Silva / João Pimenta / Clementino Amaro

1801 Algumas considerações sobre espólio não cerâmico recuperado no Largo de Jesus (Lisboa) Carlos Boavida

1815 Adereços de vidro, dos séculos XVI-XVIII, procedentes do antigo Convento de Santana de Lisboa (anéis, braceletes e contas)

Joana Gonçalves / Rosa Varela Gomes / Mário Varela Gomes

1837 Da ostentação, luxo e poder à simplicidade do uso quotidiano: arqueologia e simbologia de joias e adornos da Idade Moderna Portuguesa Jéssica Iglésias

1849 Os amuletos em Portugal - dos objetos às superstições: o coral vermelho Alexandra Vieira

1865 Cerâmicas de Vila Franca de Xira nos séculos XV e XVI Eva Pires

1879 «Não passa por teu o que me pertence». Marcas de individualização associadas a faianças do Convento de Nossa Senhora de Aracoeli, Alcácer do Sal Catarina Parreira / Íris Fragoso / Miguel Martins de Sousa

1891 Cerâmica de Leiria: alguns focos de produção

Jaqueline Pereira / André Donas-Botto

1901 Os Fornos na Rua da Biquinha, em Óbidos Hugo Silva / Filipe Oliveira

1909 A casa de Pêro Fernandes, contador dos contos de D. Manuel I: o sítio arqueológico da Silha do Alferes, Seixal (século XVI) Mariana Nunes Ferreira

1921 O Alto da Vigia (Sintra) e a vigilância e defesa da costa Alexandre Gonçalves / Sandra Santos

1937 O contexto da torre sineira da Igreja de Santa Maria de Loures Paulo Calaveira / Martim Lopes

1949 A Necrópole do Hospital Militar do Castelo de São Jorge e as práticas funerárias na Lisboa de Época Moderna Susana Henriques / Liliana Matias de Carvalho / Ana Amarante / Sofia N. Wasterlain

1963 SAND - Sarilhos Grandes Entre dois Mundos: o adro da Igreja e a Paleobiologia dos ossos humanos recuperados

Paula Alves Pereira / Roger Lee Jesus / Bruno M. Magalhães

1975 Expansão urbana da vila de Cascais no século XVII e XVIII: a intervenção arqueológica na Rua da Vitória no 15 a 17

Tiago Pereira / Vanessa Filipe

1987 Novos dados para o conhecimento do Urbanismo de Faro em época Moderna Ana Rosa 
1995 Um exemplo de Arqueologia Urbana em Alcoutim: o Antigo Edifício dos CTT Marco Fernandes / Marta Dias / Alexandra Gradim / Virgílio Lopes / Susana Gómez Martínez

2007 Palácio dos Ferrazes (Rua das Flores/Rua da Vitória, Porto): a cocheira de Domingos Oliveira Maia

Francisco Raimundo

2021 As muitas vidas de um edifício urbano: História, Arqueologia e Antropologia no antigo Recreatório Paroquial de Penafiel Helena Bernardo / Jorge Sampaio / Marta Borges

2035 O convento de Nossa Senhora da Esperança de Ponta Delgada: o contributo da arqueologia para o conhecimento de um monumento identitário João Gonçalves Araújo / N’Zinga Oliveira

2047 Arqueologia na ilha do Corvo... em busca da capela de Nossa Senhora do Rosário Tânia Manuel Casimiro / José Luís Neto / Luís Borges / Pedro Parreira

2059 Perdidos à vista da Costa. Trabalhos arqueológicos subaquáticos na Barra do Tejo Jorge Freire / José Bettencourt / Augusto Salgado

2071 Arqueologia marítima em Cabo Verde: enquadramento e primeiros resultados do projecto CONCHA

José Bettencourt / Adilson Dias / Carlos Lima / Christelle Chouzenoux / Cristóvão Fonseca / Dúnia Pereira / Gonçalo Lopes / Inês Coelho / Jaylson Monteiro / José Lima / Maria Eugénia Alves / Patrícia Carvalho / Tiago Silva

2085 Trabalhos arqueológicos na Cidade Velha (Ribeira Grande de Santiago, Cabo Verde): reflexões sobre um projecto de investigação e divulgação patrimonial André Teixeira / Jaylson Monteiro / Mariana Mateus / Nireide Tavares / Cristovão Fonseca / Gonçalo C. Lopes / Joana Bento Torres / Dúnia Pereira / André Bargão / Aurélie Mayer / Bruno Zélie / Carlos Lima / Christelle Chouzenoux / Inês Henriques / Inês Pinto Coelho / José Lima / Patrícia Carvalho / Tiago Silva

2103 A antiga fortificação de Quelba / Khor Kalba (E.A.U.). Resultados de quatro campanhas de escavações, problemáticas e perspectivas futuras Rui Carita / Rosa Varela Gomes / Mário Varela Gomes / Kamyar Kamyad

2123 Colónias para homens novos: arqueologia da colonização agrária fascista no noroeste ibérico Xurxo Ayán Vila / José Mạ . Señorán Martín 


\title{
VIEIRA GUIMARÃES (1864-1939) E A ARQUEOLOGIA EM TOMAR: UMA ABORDAGEM SOBRE O TERRITÓRIO E AS GENTES
}

\author{
João Amendoeira Peixoto' ${ }^{1}$, Ana Cristina Martins ${ }^{2}$
}

\begin{abstract}
RESUMO
Nascido em Tomar em 1864, formado em medicina pela Escola Médico Cirúrgica de Lisboa, José Vieira Guimarães falece em Lisboa em 1939. Durante a sua vida desempenhou várias ações para a valorização do património cultural da terra onde nasceu, participa em projetos arqueológicos e publicações, assim como, contacta com estudiosos como o arqueólogo José Leite de Vasconcelos.

José Vieira Guimarães envolve-se em associações e academias, é sócio da Associação dos Arqueólogos Portugueses, participa em escavações, investiga, publica artigos e livros, participa em congressos, firma a hipótese, de Seilium romana se situar em Tomar.

Apresentamos conteúdo inédito sobre a participação num congresso em 1923, assim como, consideramos que comete uma falha, em nossa opinião, a prova potencial do seu trabalho.

Palavras-chave: José Vieira Guimarães, Tomar, Arqueologia, Seilium, Território.
\end{abstract}

\begin{abstract}
Born in Tomar in 1864, graduated in medicine from Escola Médico Cirúrgica de Lisboa, José Vieira Guimarães died in Lisbon in 1939. During his life performed several actions to enhance cultural heritage from Tomar. He had participated in archaeological projects, publications and contacted with scholars like the archaeologist José Leite de Vasconcelos.

José Vieira Guimarães was involved in associations and academies, was a member of Association of Portuguese Archaeologists, had participated in excavations, investigated, published articles and books, participated in congresses, confirmed the hypothesis of Seilium romana being located in Tomar.

We present unprecedented content about his participation in a congress in 1923, as well as, we consider that he had fault with the potential proof of his work.

Keywords: José Vieira Guimarães, Tomar, Archaeology, Seilium, Territory.
\end{abstract}

\section{ENQUADRAMENTO INTRODUTÓRIO}

A comunicação "Vieira Guimarães (1864-1939) e a Arqueologia em Tomar: uma abordagem sobre o território e as gentes" presente no III Congresso da Associação dos Arqueólogos Portugueses, que decorre de 19 a 22 de novembro de 2020, inclui conteúdo incorporado no trabalho de doutoramento em História e Filosofia da Ciência da Universidade de Évora, coordenação da Prof. Doutora Maria de Fátima Nunes, intitulado: Medicina e Património Cultural em Tomar - o caso de José Vieira da Silva Guimarães, e orientação da Prof. Doutora Ana Cristina Martins.

\section{ARQUEOLOGIA E PATRIMÓNIO CULTURAL EM TOMAR}

Sobre a arqueologia em Tomar, é necessário relembrar o século XIX em que o conhecimento da Antiguidade Clássica é cultivado pelas Academias e Socieda-

\footnotetext{
1. Universidade de Évora; joaoalveı@gmail.com

2. Universidade de Évora; acmartins@uevora.pt
} 
des eruditas, sendo de dar destaque à Associação dos Arquitetos Civis Portugueses, fundada em 1863 por Joaquim Possidónio da Silva (1806-1896) ${ }^{3}$, que tinha em Tomar como sócio correspondente Pedro de Roure Pietra (1815-1874)4, elemento que realizou escavações na região (Peixoto, 2020). Esta associação é designada, a partir de 1871, através da agregação da componente arqueológica, por Real Associação dos Arquitetos Civis e Arqueólogos Portugueses (RAACAP) (Martins, 2013; Martins, 2015; Martins, 2016).

De Pedro de Roure Pietra, das várias intervenções arqueológicas que executa, é de assinalar a descoberta de cipos romanos em 1857 , confirmação da presença romana em terras nabantinas, tendo Joaquim Possidónio da Silva publicado um artigo sobre $\mathrm{Na}$ bância em 1881, onde relembra o seu correspondente, no Boletim da Real Associação dos Architectos Civis e Archeologos Portuguezes, e refere a descoberta da cidade romana Nabância em Portugal, neste caso concreto em Marmelais5. (Silva, 1881) É, no entanto, de assinalar que Nabância é mencionada e identificada na região de Tomar por outros autores de séculos anteriores a esta publicação. ${ }^{6}$

Tendo em consideração que os principais centros de conhecimento estavam localizados em Lisboa,

3. Joaquim Possidónio Narciso da Silva (1806-1896), fidalgo e arquiteto da Casa Real, fundador da Associação dos Arquitetos Civis Portugueses em 1863. (Martins, 2013)

4. Pedro de Roure Schiappa Pietra (1815-1874), administrador de fábricas, agrónomo, político, sócio correspondente n.o 68, junho de1864, da Associação dos Arquitetos Civis Portugueses. (Peixoto, 2020)

5. Possidónio da Silva localiza a sua descoberta em "Marmelaio" no lugar de Marmelais, que pode ser subdivido atualmente em Marmelais de Baixo e Marmelais de Cima, localizando-o a dois $\mathrm{km}$ de Tomar e a um $\mathrm{km}$ da margem esquerda do rio Nabão, situado na antiga freguesia de Santa Maria dos Olivais, hoje União de Freguesias de Tomar. (Silva, 1895). Sobre este assunto, a Direção Geral do Património Cultural atribui outra designação às "ruínas de Nabância", a de "Vila romana de Cardais", dado tratar-se do sítio de Cardais em Marmelais de baixo.(DGPC, 2020) De acordo com Ana Cristina Martins (2003), este tema foi bastante debatido pelo Concelho Superior de Monumentos, no que toca ao valor histórico e arqueológico do sítio ponderando-se a hipótese de desclassificação. (Martins, 2003)

6. Vide, a título de exemplo, a obra "História da Vida e Martyrio da Gloriosa Virgem Santa Eria, Freira da Ordem Patriarcha Sam Bento, natural de Nabancia, que hoje he a notavel Villa de Thomar em o Reyno de Portugal" publicado em 1618 e da autoria do Freire Isidoro da Barreira.
Coimbra e Porto, por motivos de recursos humanos e materiais, a dimensão do património cultural de Tomar, através da sua história, monumentos e ruínas, levaram alguns eruditos a realizar intervenções na região, surgindo Vieira Guimarães nesta contenda. (Martins, 2016)

José Vieira da Silva Guimarães (1864-1939), natural de Tomar e formado em Medicina na Escola Médico Cirúrgica de Lisboa, realiza todo um percurso de vida centrado na valorização da terra de onde é natural, tendo participado em diversas associações, academias e sociedades, publicado obras literárias, recebido o grau de Comendador da Ordem de Cristo em 1903, é eleito deputado da nação e torna-se professor de História e Geografia no Liceu Camões em Lisboa desde 1905, ocupando o cargo de diretor da Sociedade Propaganda de Portugal em 1914, entre mais, torna-se sócio correspondente da RAACAP em 1905. (Peixoto, 2019) (Figura 1)

Sobre José Vieira Guimarães há dois assuntos de relevância na história da Arqueologia em Tomar. O primeiro acontece em 1895 , ainda como estudante de medicina, em que participa numa investigação na igreja de Santa Maria dos Olivais; sobre o segundo assunto, na década de vinte do século XX, em que publica a obra THOMAR S.ta IRIA (1927) sobre as origens romanas de Tomar, teoriza a localização de Seilium na região nabantina, sendo necessário realçar que o envolvimento de José Vieira Guimarães na Arqueologia em Tomar, entre estes dois momentos, surge como permanente tal como teremos a oportunidade de verificar. (Guimarães, 1927)

\section{AS COMEMORAÇÕES DO CENTENÁRIO DE D. GUALDIM PAIS}

A relevância da história local é constantemente elevada na segunda metade do século XIX pela população tomarense com enfoque através da imprensa e comemorações.

José Vieira da Silva Guimarães idealiza em 1895 a criação de um centenário dedicado a D. Gualdim Pais, quarto mestre da Ordem dos Templários, fundador do castelo e vila de Tomar, que incorpora uma série de festejos onde os monumentos, história local e indústria nabantina são colocados em destaque através dos mais diversos meios de divulgação tal como a imprensa local e nacional, assim como, de uma exposição agrícola e industrial concelhia sobre a qual, o estudante de medicina, publica o Catálogo 
da Exposição Industrial-Agrícola de Thomar. Esta será a primeira publicação de José Vieira Guimarães, nela discorre sobre as origens de Tomar, remontando a epochas romanas, acharemos a origem da famosa Nabancia, relembrando que é na região onde se situam estas ruínas que D. Gualdim Pais escolhe a edificação do castelo. (Guimarães, 1895, p. 3)

Na edição do semanário local A Verdade, № ${ }^{\circ} 81$ de 14 de abril de 1895, meses antes das comemorações dedicadas ao fundador de Tomar, é publicada a notícia "Última Hora", onde revela que Manuel Henrique Pinto e José Vieira da Silva Guimarães, após investigações, descobrem a campa e repectivo epitaphio de D. Gualdim Paes, os quaes ha muito se consideravam perdidos ou anniquillado. (Magalhães, 1895 , p. 3) (Figura 2).

Esta descoberta envolveu escavações na Igreja de Santa Maria dos Olivais ${ }^{7}$ em Tomar, sendo que os elementos sepulcrais do mestre templário se encontravam desaparecidos tal como nos revela Pedro de Roure Pietra numa publicação na Gazeta de Portugal em $1863^{8}$, onde confirma o facto quando se refere às obras mandadas erguer na igreja durante os reinados de D. Manuel I e de D. João III: os mestres haviam barbaramente (...) sepultados os ossos em uma das capellas laterais, que então foram abertas, collocando uma inscripção na parede, que o padre Carvalho diz ter visto, mas que ainda até hoje não foi possivel descobrir. (Costa, 1712; Pietra, 1863, p.1)

A lápide parietal do túmulo de D. Gualdim Pais, encontra-se hoje exposta na Igreja de Santa Maria dos Olivais em Tomar, no entanto, sobre a campa, tal como é noticiado, ou sepulcro deste cavaleiro templá-

7. Templo de origens beneditinas, reconstruído no século XII pelos templários, também denominado de Igreja de Santa Maria do Olival, está localizado na antiga freguesia de Santa Maria dos Olivais em Tomar, hoje pertencente à União das Freguesias de Tomar, entre a Avenida D. Maria II e a Rua Aquiles da Mota Lima.

8. Através de uma carta de Pedro de Roure Pietra presente na correspondência de Possidónio da Silva, foi possível localizar junto da Biblioteca Nacional de Portugal of folhetim da autoria de Pedro Pietra presente na Gazeta de Portugal (Pietra, 1863), que inclui a informação sobre o desaparecimento da inscrição dedicada ao mestre templário D. Gualdim Pais. Segundo Pietra (1963), a fonte da existência desta inscrição é o Tomo III da Corografia portugueza e descripçam topografica do famoso Reyno de Portugal do padre António Carvalho da Costa; informação que se confirma consultando a obra na página 156: (...) em cuja parede se pozo epitáfio de D. Gualdim (...). (Costa, 1712) rio, é presentemente desconhecida a sua existência. Necessário ressalvar que a edição seguinte do jornal A Verdade, a № 782 de 21 de abril, refere igualmente o envolvimento de José da Silva Magalhães na descoberta, arquitecto e irmão do editor deste jornal, António da Silva Magalhães (1834-1897) ${ }^{9}$ : esquecemos de dizer, já no número passado, que o Sr. José da Silva Magalhães tem sido um excellente cooperador nas investigações a que os nossos amigos Pinto e o Guimarães tem precedido em Sta. Maria dos Olivaes. (Magalhães, 1895a, p. 2)

Nesta edição é mencionado também o conteúdo da inscrição descoberta na igreja de Santa Maria do Olival em Tomar:

Dissemos no número passado que se tinha encontrado o glorioso epithaphio do glorioso fundador da nossa formosa cidade. Devido, como também dissemos, às investigações dos nossos amigos Manuel H. Pinto e Vieira Guimarães, e que se tinha alcançado aquele bom resultado $^{\text {10 }}$ (Magalhães, 1895a, p. 2)

9. António da Silva Magalhães (1834-1897), fotógrafo, editor, fundador e proprietário da Typografia Photographia Tomarense, onde se imprimiu o primeiro jornal local A Emancipação, ao qual se seguiu o jornal A Verdade por si criado do qual é diretor e proprietário, dedicou-se igualmente ao colecionismo, teatro, política e arqueologia. É próximo de José Vieira Guimarães, tendo este lhe dedicado alguns dos seus trabalhos escritos. (Ventura, 2014)

10. Por considerarmos de utilidade para este artigo, transcrevemos a restante informação desta notícia: (...) Pois tratando-se agora de levar a efeito a celebração do $7^{\circ}$ centenário do seu passamento, vinha lançar imensa luz sobre este notável acontecimento e coroar a obra benemérita a que aquelles nossos amigos se têm devotado. A inscrição é a mesma que estava no grande túmulo onde admiram por longos séculos os venerados restos de tão illustre guerreiro. São prova disso a forma da cruz dos Templários que se acha no principio do epithaphio, a era de Cézar, que só no reinado de D. João I começou a ser substituida pela de Christo. E os escriptores antigos que merecem credito pelo escriptos everassidade com que escreveram as suas chronicas. Diz ele em latim: Oblit frater Gualdinus magister militum templo portugalie era milesima ducentosi (...) tertia, tertio Ibidus octobris. Hic castrum Tomaris cum multis aliis populauit. requiescat in pace. Amen. A tradução deve ser: Faleceu o irmão Gualdim mestre dos cavaleiros do Templo em Portugal ao 13 d'outubro de 1195. Este, com muitos outros cavalleiros povoou o castello de Thomar. Descanse em Paz. Amen.

Por aqui se vê pois que a morte de Gualdim Pais, esse Templário illustre a quem Portugal tanto deve pela ações homérias de valor e lealdade e pelo seu alto tato politico, foi a 13 de outubro de 1195 
Surge neste jornal outra informação relevante, sobre uma nova descoberta na Igreja de Santa Maria dos Olivais, refere-se à sua data de fundação:

Mais um preciso indicio se descobriu um dia d'esta semana e se chega a esclarecer melhor, talvez venha em auxílio d'aquelles que depois de longos estudos, se incliname a dizer que tudo que hoje ainda se vê do principal em SMaria é (?) de Gualdim Paes. Na porta principal em duas pedras veem se algumas letras, indicando que grande inscrição alli tivesse existido. Do que resta só há a palavras Era e mais 2 XIII que parece indicar o anno da fundação d'aquelle templo. Pois, se se chegar a recompôr aquella era, sômos levados a crer que será a de 1213, nos quaes tirando 38 annos de avança da era de Cezar, temos o anno de 1175, anno em que Gualdim Paes era vivo (Magalhães, 1895a, p. 2)

Com base na bibliografia consultada e na informação disponibilizada pela Direção Geral do Património Cultural, não há indícios desta data e da fundação templária da Igreja de Santa Maria dos Olivais, remetendo para o século XII: A primitiva igreja terá sido edificada no século XII, por iniciativa de D. Gualdim Pais, mestre da Ordem do Templo, para cemitério dos freires. (...). Em visita ao local, por observação direta, foi possível identificar, na porta principal, a inscrição mencionada. (Direção Geral do Património Cultural, 2020)

Manuel Henrique Pinto (1853-1912), noticiado como participante nesta descoberta na companhia de José Vieira Guimarães, trata-se do pintor naturalista, elemento do Grupo O Leão e próximo de José Malhoa (1855-1933), ambos pintores do primeiro naturalismo português, que em 1895 cumpria funções como diretor da Escola de Desenho Industrial Jácome Ratton em Tomar desde 1888, ano em que ocupa o lugar do seu falecido amigo Cipriano Martins (1841-1888), outro elemento do Grupo O Leão. (Museu Centro de Artes Figueiró dos Vinhos, 2020)

Neste mesmo ano é publicada a obra Inscripções Portuguezas (1895) da autoria de Luciano Cordeiro (1844-19oo), historiador e geógrafo português, onde o epitáfio está incluído na obra, tendo o autor feito referência ao centenário valorizando a,

feliz ideia de tomar por tema o nome e a memória do valente Templario portuguez Galdino Paes, tão deploravelmente esquecido tambem, e de quem póde dizer-se que foi, alem de fundador de Thomar, um dos mais intrepidos e persistentes cooperadores da fundação de Portugal (Cordeiro, 1895, p. 46) (Figura 3).

Luciano Cordeiro menciona nesta obra a sua amizade com o pintor Manuel Henrique Pinto, assim como, uma ligação profissional ao revelar que o mesmo o tem auxiliado na recolha de calcos de inscrições portuguesas. O geógrafo confirma igualmente a presença de mais dois amigos presentes na investigação de Santa Maria dos Olivais, que de acordo com a informação já apresentada correspondem a José Vieira Guimarães e a José da Silva Magalhães, que resultou na descoberta do epitáfio de D. Gualdim Pais, tal como nos revela:

Sob aquella idéa se reanimou o empenho do meu amigo e distincto director-professor da Escola Industrial d'aquella cidade, sr. Manuel Henrique Pinto, de encontrar a jazida dos restos do glorioso Templario. Aproveito a occasião para dizer, com reconhecimento, que o sr. Pinto tem sido o meu mais dedicado e caloroso auxiliar n'esta colheita de calcos de inscripções portuguezas ${ }^{11}$ (Cordeiro, 1895, p. 46)

O Diario Illustrado de Lisboa, edição de 13 de outubro de 1895, № 8:104, assinala igualmente o centenário, dedicando uma crónica à vida de D. Gualdim Pais onde já revela a existência da inscrição recentemente descoberta, assim como, inclui duas ilustrações dedicadas à ocasião e notícia alguns acontecimentos sobre este centenário. (Silva, 1895) (Figura 4).

11. Por considerarmos de utilidade para este artigo, transcrevemos a restante informação sobre este assunto: (...) Honra lhe seja, que n'isso não é a mim, mas á Historia e ao paiz, que presta um bello serviço.

Obtendo licença para sondar as paredes d'aquella interessantissima e vetusta igreja de Santa Maria do Olival ou dos Olivaes, que por si dava assumpto para uma soberba monographia sobre a historia da architectura nacional, o sr. Pinto, com dois amigos egualmente interessados n'esta pesquiza, começou-a e teve a fortuna de, ás primeiras tentativas, encontrar a pedra (naturalmente um dos lados do sarcophago), em que está, nitida e graciosamente cavada a inscripção de que tirou e me enviou o magnifico calco, em poucos minutos reproduzido pelo lapis primoroso e firme de Casanova. Como se vê, a inscripção não offerece hesitações ou duvidas de leitura ou de contemporaneidade, esta ultima perfeitamente flagrante, para quem conhece a epigraphia tumular do tempo, com as suas cruzes espalmadas (pattées) iniciaes, com as maiusculas oscillando entre o romano e o gothico, com o seu pautado, até com a sua redacção dos velhos obituarios e livros de calendas, monasticos. (Cordeiro, 1895, p. 46) 
Esta descoberta permitiu aumentar a curiosidade sobre estas comemorações, comprovável pela adesão nacional, onde hotéis e habitações da região de Tomar, foram amplamente preenchidos de forasteiros, tal como reporta a imprensa local, durante os dias 13, 14 e 15 de outubro de 1895 .

\section{SEILIUM ROMANA EM TOMAR}

Em 1895, José Leite de Vasconcelos ${ }^{12}$ publica no Archeologo Portugues o artigo Antiguidades romanas de Thomar, onde cita o jornal A Verdade, $\mathrm{n}^{\circ} 703$ de 15 de outubro de 1893, do editor António da Silva Magalhães; artigo sobre vestígios da importante cidade de Nabancia, que testemunha o aparecimento de uma cabeça de estátua romana, assim como, de moedas romanas, incluindo de uma em particular que a imprensa local faz surgir a palavra NABAENTVUM, considerando-se, assim, provar a existência de Nabância em Tomar. (Magalhães, 1893; Vasconcelos, 1895) (Figura 5).

Relativamente ao assunto Nabância, o arqueólogo José Leite de Vasconcelos demonstra a seguinte posição: Á cêrca do nome Nabancia dado, quer as ruínas romanas exploradas pelo benemerito archeologo, o SR. Possidonio da Silva, e que existem perto de Tomar, - as quais visitei em 1890 na amável companhia do Sr. Antonio da Silva Magalhães, a quem se refere a notícia antecedente, quer as outras ruínas situadas em local diverso faço por em quanto algumas reservas. (Vasconcelos, 1895, p. 14)

Para além de demonstrar as suas reservas sobre a existência de uma povoação romana que se denominaria Nabância, questiona igualmente a moeda romana que aparentava fazer surgir a palavra NABAENTVUM. José Leite de Vasconcelos refere que se tomou a palavra "CASCANTVM" pela anterior, referindo-se, assim, ao município de Cascanto (...) que ficava na Hispania Citerior (...) muito longe

\footnotetext{
12. José Leite de Vasconcelos Pereira (1858-1941), formado em Ciencias Naturais em 1881 e em Medicina na Escola Médico Cirúrgica do Porto em 1886, desenvolve como tese "A Evolução da Linguagem”, já com sinais de duas paixões: a arqueologia e a filologia. Trabalhou na Biblioteca Nacional 23 anos, formou-se em Filologia em Paris, fundou o Museu Etnográfico Português, atual Museu Nacional de Arqueologia, tendo desenvolvido várias atividades e investigações neste campo. (Mariotto, 2020)
}

do município nabantino. No entanto, o arqueológo assinala várias descobertas que provam a presença romana na região, inclusive na Torre de Menagem do Castelo de Tomar, considerando que os vestígios romanos se estendem numa área bastante dilatada. (Vasconcelos, 1895, p. 14)

Desta forma, José Leite de Vasconcelos, em 1895, questiona a opinião local e a de Joaquim Possidónio da Silva sobre a real existência de uma povoação romana de nome Nabância, mostrando igualmente uma diferente leitura da moeda de cobre, que serviria de prova física, dando-lhe uma diferente origem.

Noutra publicação de José Leite de Vasconcelos no Archeologo Português de 1914, o assunto Nabância é novamente abordado, sendo que, desta vez, se refere à publicação de uma carta que o arqueólogo escreveu ao Presidente do Conselho dos Monumentos Nacionais sobre a sua ida a Tomar no sentido de examinar as ruínas romanas. (Vasconcelos, 1914, p. 146)

Nesta carta, José Leite Vasconcelos refere que se dirigiu para o local das ruínas na companhia do meu colega e amigo Dr. Vieira Guimarães, que, sabendo da visita, quis dar-me o gosto de andar comigo. A visita é realizada ao sítio Cardais, onde descreve os achados e local, que recorda ter sido crismado por Possidónio da Silva como Nabância, assim como, desenha objetos que encontrou guardados no local "numa casa moderna".

José Leite de Vasconcelos contesta a localização de Nabância em Cardais concebida por Possidónio da Silva, explicando igualmente que este fundador do Museu do Carmo, desconheceria o mais antigo livro que nos fala de Nabancia (...) o Breviarium de Braga (...) aí se conta o martírio de Santa Iria (...) tinham o governo de Nabância (qui principabantur apud NABANTIAM); lenda que acontece na região de Tomar e que localiza os antigos mosteiros beneditinos onde hoje se situam o Convento de Santa Iria e a Igreja de Santa Maria dos Olivais. (Vasconcelos, 1914, p. 148; Arquivo Nacional Torre do Tombo, 202O; Convento de Cristo, 202O)

De acordo com José Leite de Vasconcelos, se há um local para situar Nabância, esta se situaria na margem esquerda do rio, à entrada de Tomar para quem vai de Coimbra", ou seja, em Santa Maria dos Olivais, revelando que segundo o Sr. Vieira Guimarães, alicerces de casas, tijolos queimados (lares), cima- 
lhas, fragmentos de estátuas, etc. são frequentes de encontrar nessa localização. ${ }^{13}$

Esta informação permite-nos perceber que José Vieira Guimarães acompanha os achados arqueológicos da região, considerando que é sócio correspondente da RAACAP desde 1905 e representante em Tomar do concelho dos monumentos desde 1902, no entanto, não sendo permitido afirmar que participa diretamente nas escavações arqueológicas relacionadas com achados romanos, com base nas informações apresentadas por Leite de Vasconcelos sobre Nabância e no envolvimento de José Vieira Guimarães nas pesquisas de 1895 e ligação de proximidade com a família Silva Magalhães, permite deduzir a sua participação nas pesquisas arqueológicas.

José Leite de Vasconcelos, antes de concluir esta sua carta, informa sobre duas pedras de certo mérito que foram indicadas pelo Dr. Vieira Guimarães. A primeira é romana e encontra-se na base da Torre de Menagem do castelo de Tomar, descoberta em 1912 quando a torre se desentulhou, tendo inscrito: ao Génio do município; ou seja; GENIO MVNICIPI. (Vasconcelos, 1914)

Segundo o arqueólogo, este facto prova que a antiga povoação de Tomar de que provém Tomar pertenceria à classe dos municípios; quanto à segunda inscrição é de origem medieval. José Leite de Vasconcelos conclui a carta publicada, sobre a importância da conservação das estruturas romanas, questionando o trabalho de Joaquim Possidónio da Silva. ${ }^{14}$

Sobre este mesmo tema, José Vieira Guimarães publica em 1927 a obra Thomar Sta. Iria, onde questiona a localização da povoação de Sellium, assinalada por Ptolomeu e incluída do Itinerário antonino, sendo a designação gráfica atual Seilium ${ }^{15}$. Nesta mesma

13. Santa Maria dos Olivais, é uma antiga freguesia extinta em 2012-2013, com cerca de 17, $23^{\mathrm{Km} 2}$ de área, no concelho de Tomar, que inclui nela a Igreja de Santa Maria do Olival (C.M.T., 2020). As escavações arqueológicas na região, no que toca à época romana, demonstram vários vestígios, incluindo o Forum descoberto atrás do Quartel dos Bombeiros e diversos edifícios habitacionais como os descobertos na Alameda 1ํㅡe Março em Tomar. (Batata, 1997)

14. De acordo com Jorge Custódio (2008), o assunto Nabância é um dos processos mais antigos do serviço de monumentos de Portugal, que irá culminar com o seu abandono declarado e fim do mito de Nabância.

15. De acordo com Salete da Ponte (1994), nas fontes históricas antigas como o Itinerário de Antonino a grafia do termo Sellium é deturpada, considerando que o termo Seiliense obra, para além de relembrar os dois cipos romanos descobertos por Pedro de Roure Pietra e que localiza no Museu do Carmo, lembra que os escritores têm feito situar Sellium em Seice, hoje humilde aldeia, num estreito vale de Ourém, sem que para isso apresentem sólida razão, a não ser a semelhança das duas palavras começarem por S ou por C conforme a ortografia de cada um, ou em Seixo, povoação cujo nome se encontra muitas vezes, como diz Hubner, mas não refere. (Guimarães, 1927, p. 6)

José Vieira Guimarães contradiz este raciocínio, com base em estudos de Onomatologia, referindo que Sellium não poderia formar Seice pelo facto desta palavra derivar da latina Salix que com o sufixo airus, na nossa língua, deu a palavra salgueiro que originou também Saúz, Seice, donde o nome de Seiça, ressalvando que o lugar apresenta abundância de água e exemplares daquela árvore incluindo uma de maior corpulência.

O médico nabantino sustenta que Antonino e Ptolomeu são os únicos escritores que anunciam a existência de Sellium, sendo que Ptolomeu, grego do século II, na sua Geografia enumera Sellium como uma das povoações importantes da Lusitânia, enquanto que o Itinerário antonino, do tempo de Júlio César e revisto nos séculos III e IV, localiza a povoação de Sellium a 32 milhas de Scalabis e a 44 de Aeminium. Considerando Scalabis Santarém e Aeminium Coimbra, José Vieira Guimarães traçou as distâncias em relação a Tomar. Em comparação com os dados do Itinerário, para com Coimbra há um erro de 164 metros; e entre Santarém e Tomar encontra uma diferença de 108 metros. Valores que José Vieira Guimarães considera irrelevantes e demonstrativos de que Sellium se situa em Tomar. (Guimarães, 1927, pp.7-10)

Indo ao encontro de uma das fontes de José Vieira Guimarães, na obra Noticias archeologicas de Portugal de Emílio Hubner de 1871, a ligação entre Sellium e a povoação de Seixo é apresentada de forma bastante duvidosa pelo autor, tal como o demonstra em virtude de uma remota semelhança de palavras, sendo de destacar que este parágrafo surge entre outros dois referentes à região de Tomar, sem que este assunto lhes seja associado, o que cria a possibilidade deste trabalho ter contribuído bastante para o

referido em inscrições funerárias permite chegar ao consenso de "Sellium = Seilium". (Ponte, 1994) José Vieira Guimarães, depara-se com esta situação a que denomina de "paradoxo”. (Guimarães, 1927) 
pensamento de José Vieira Guimarães. Outra possível fonte, da autoria de João Maria Baptista e publicada em 1876, apresenta esta mesma leitura, no entanto, demonstra a proximidade entre a povoação de Seixo e Tomar, tal como apresenta: Em Seixo ou Ceice próximo de Thomar collocam alguns a cidade Sellium só pela semelhança remota das palavras e por ser Sellium a immediata a Thomar no Itinerario. (Guimarães, 1927)

José Vieira Guimarães comete, em nossa opinião, um erro na sua obra, que lhe valeria a comprovação da sua teoria, da localização de Sellium em Tomar, quando menciona o conteúdo de uma estela romana presente em Lorvão referente a um jovem seiliense, onde surge o paradoxo de não se escrever selliense. Sobre este assunto, o autor refere: Esta pedra procede de Lorvão, povoação próxima da antiga Aeminium, e a 44 milhas de Sellium, o que dá a máxima probabilidade a que este seiliense, tivesse sido natural de Sellium e não de Seilense, povoação galega, conhecida por uma inscrição que vem no Corpus II, $2562 .{ }^{16}$ (Guimarães, 1927, p. 8)

Esta informação abordada por José Vieira Guimarães parece estar relacionada com um artigo de José Leite Vasconcelos publicado em 1914, Inscrição romana de Lorvão, onde menciona que o,

epíteto pátrio Seiliensis traz-nos à mente o adjectivo geográfico Seilensis de uma inscrição galega do Corpus, II, 2562, e o nome Sellium, que nesta forma figura no Itenerário de Antonino (...) é bastante provável que Seiliensis não se refira a uma terceira povoação, e se relacione antes com Sellium do que com o galego Seilensis (Vasconcelos, 1914b, p. 366).

José Leite de Vasconceles acrescenta, que segundo este raciocínio, é errónea a forma Sellium, que deve substituir-se por Seilium, defendendo que a origem desta situação poderá estar nos antigos manuscritos, onde a letra "I" foi tomada por uma "L". (Vasconcelos, 1914a)

Na realidade, o conteúdo desta inscrição galega presente no Corpus II, 2562, que é ignorada no seu conteúdo escrito por José Leite de Vasconcelos e poste-

16. Esta citação presente na página 8 da obra Thomar Sta. Iria (1927), demonstra o "paradoxo" de José Vieira Guimarães, em o habitante de Sellium não se designar de selliense, assim como, desconhecer o conteúdo da inscrição galega, que resolveria esta sua questão. (Guimarães, 1927) riormente por José Vieira Guimarães, é dedicada a um indivíduo romano, cujo nome surge igualmente numa segunda estela presente na Torre de Menagem do castelo de Tomar, contendo ambas as dedicatórias o nome da sua mãe Sabinula. De assinalar a presença, na mesma torre, de uma terceira inscrição relacionada com este elemento feminino.

A inscrição galega datada de II d.C., foi localizada numa praia ${ }^{17}$ perto de Finisterra por volta de 1750, tendo servido como base de altar de uma igreja em Queiruga até 1822, data em que foi mandada retirar por não se considerar correto o seu uso religioso, no entanto, mantém-se exposta numa parede lateral do mesmo espaço religioso. (Bayón, 1997; Património Galego, 2012) (Figura 6).

A leitura da inscrição:

C(aius) ATTIVS ATTIANVS RVFINVS SEILIENSIS

ANN(orum) XXII H(ic) S(utis) E(st)

RVFVS PATER ET SABINVLA MATER FECE

(Caio Attio Attiano Rufino seiliense aqui morreu com a idade de 22 anos Pai Rufino e mãe Sabinula mandaram erguer)

Sobre as estelas presentes na Torre de Menagem em Tomar, os seus respetivos conteúdos comprovam a ligação à inscrição anterior: (Batata et al., 1983)

RVFVS ET SABINVLA/VXOR/SIBI
Rufus e Sabinula sua mulher
(fez este monumento em memória do seu marido)
G [aio]ATTIO/ATTIA/NO RVFINO/SABINVLA/
MATER P[osuit]

A Gaio Attio Attiano Rufino sua mãe fez (este monumento) $)^{18}$

17. De acordo com a história local galega, a estela é descoberta por pescadores no areal da praia, após uma tempestade marítima que revoltou o areal, tal como nos documenta Bayón (1997): Sucedió que un fortísimo temporal removió la masa arenosa de la playa y la dejó al descubierto. Las Gentes marineras, por el pretigio de su aparicón milagrosa, considerandola algo sagrado, le dieron cobijo en el templo parroquial, ocupando el ara del altar Mayor. (Bayón, 1997) O local deste acontecimento é a praia de Seiras em Porto do Son, Galiza. (Património Galego, 2012)

18. Os autores do catálogo da exposição de 1983, nomeiam Gaio em vez de Caio, da mesma forma como José Vieira Guimarães o faz na obra Thomar Sta. Iria (1927), quando se refere a esta mesma estela presente na Torre de Menagem 
A inscrição dedicada a Rufus por Sabinula, sua mulher, é datada de I d.C. - II d.C., encontra-se na verga da janela do $1^{\circ}$ andar do lado sul da Torre de Menagem, enquanto que a dedicada a Caio, com a mesma datação, situa-se na pardeira de uma janela do $1^{\circ}$ andar do lado sul da Torre de Menagem.

Na obra Thomar Sta. Iria (1927) de José Vieira Guimarães, as inscrições tomarenses apresentadas neste artigo, referentes a Sabinula, estão documentadas, no entanto, acontece a pouco provável situação, desconhecida pelo médico nabantino, de o indivíduo por si referenciado pela inscrição galega, que identifica, localizando-a no Corpus II, 2562, corresponder ao mesmo que se encontra mencionado noutra inscrição presente na Torre de Menagem em Tomar, filho de Sabinula. Os nomes dos pais de $R u$ fino comprovam esta ligação, o que na realidade a ser percecionada por José Vieira Guimarães, consideramos que teria sido a sua prova fulcral para complementar a teoria sobre Sellium. ${ }^{19}$

em Tomar. No nosso entender esta leitura é introduzida em erro, pois se se observar a fotografia 11 do catálogo da exposição, o primeiro nome encontra-se superiormente encoberto por outra estrutura da Torre de Menagem, induzindo parecer a letra “G”. Este facto é comprovável através da leitura da inscrição de Queiruga, onde é evidente tratar-se de um “C”, cuja letra em pedra calcária é semelhante à estela de Tomar. Temos desta forma, Caio em vez de Gaio. (Guimarães, 1927; Batata et al., 1983)

19. No século XII, os templários utilizaram as ruínas das antigas civilizações romana e bárbara da região de Tomar, para erguer o castelo e convento. O Catálogo Tomar na arte antiga (1983), apresenta um espólio em imagem de achados nabantinos, onde as duas inscrições funerárias dedicadas por Sabinula surgem em fotografia 9, 10 e 11. (Batata et al., 1983) Segundo os autores, as estelas terão sido encontradas na margem esquerda do rio Nabão. De acordo com estudos galegos (1959), a lápide de Queiruga e de Tomar referem-se ao mesmo indivíduo, sendo que se trata de um cenotáfio, sustentando Salete da Ponte (1994), de que este seiliense "falecera em terras da Galiza". (Castillo \& D 'Ors, 1959; Centro de Estudios Historicos, 1959; Ponte, 1994, p.138) O coautor deste artigo João Amendoeira Peixoto, apresenta uma nova possibilidade sobre este assunto, em crónica publicada no Jornal Cidade de Tomar de 14 de fevereiro de 2020 , considera a existência de uma quarta inscrição descoberta em Deva (Chester, Inglaterra), referente a um elemento da Legio Valeria XX Vitrix, Caius Attius Rufinus, contemporânea às anteriores, que pode corresponder ao seiliense de 22 anos, sugerindo que a estela galega é mandada erguer pela família simbolicamente perto de Finisterra, local terrestre mais a ocidente, tratando-se igualmente de um cenotáfio. (Peixoto, 2020a)
A localização de Seilium em Tomar é hoje aceite pela comunidade científica, no entanto, foi contestada por alguns historiógrafos durante décadas, tais como Amorim Rosa (1900-1976), que na obra História de Tomar (1965), composta por dois volumes, enobrece a visão da existência de uma Nabância romana em Tomar, sem mencionar Seilium, referindo-se a José Vieira Guimarães da seguinte forma: $E$ isto escreveu Vieira Guimarães, que sempre quis negar, por razões que não vêm para o caso, a existência, evidente, de Nabância. (Rosa, 1965, p. 20)

Por outro lado, esta mesma obra dá-nos uma prova escrita do envolvimento de José Vieira Guimarães em projetos arqueológicos em Tomar, quando se refere à descoberta de estruturas de edifícios, moedas romanas de vários imperadores, tijolos, vasos e outros instrumentos, na zona da Cerrada de João do Couto e envolvente, por diversos indivíduos em várias décadas de achados arqueológicos: Conjugando o que o major Figueiredo encontrou na sanja $G$ com as cornijas encontradas por Possidónio da Silva e Dr. Vieira Guimarães, e os pedaços de fustes que falava o Dr. Sousa. (Rosa, 1965, p. 21)

De acordo com o site de Arqueologia do Património Cultural, na descrição da última escavação de 2008/2009, surgem achados da época romana nos trabalhos arqueológicos desenvolvidos junto à Igreja de Santa Maria dos Olivais em Tomar:

Os trabalhos arqueológicos desenvolvidos nas proximidades da Igreja de Santa Maria do Olival (Tomar-Santarém) integraram-se no projeto de minimização de impactos - II Fase da empreitada de construção dos arranjos exteriores no Flecheiro, proposto pela Tomar Polis. A intervenção arqueológica recaiu na área da necrópole medieval e moderna de Santa Maria do Olival. Permitiu identificar ainda estruturas habitacionais $e$ alguns fornos cerâmicos de cronologia romana, que parecem enquadrar-se na área extramuros da cidade romana de Sellium. (Portal do Arqueólogo, 202Oa)

Complementando a informação da presença de fornos cerâmicos romanos sob a necrópole medieval, torna-se complementar referir um artigo publicado pela Universidade de Letras da Universidade de Coimbra em 2002, intitulado Marcas de oficina em tijolos romanos de Seilium, onde os autores identificam marcas de oficina com as letras RPS em material encontrado na região de Tomar, Cardais e no Cerrado do Couto, datado de I d.C.. (Fernandes \& Ferreira, 2002) 
Os investigadores referem que a menção da $\mathrm{R}(\mathrm{es})$ $\mathrm{P}$ (ublica) é habitualmente representada pelas siglas R. P.; considerando a localização do tijolo, propuseram a seguinte interpretação: $\mathrm{R}(\mathrm{es}) \mathrm{P}$ (ublica) S(eiliensis) A República Seiliense.

Neste artigo, publicado em 2002, os autores desconhecem a existência de fornos de cerâmica em Seilium, considerando apenas o conhecimento de um forno extramuros:

A possibilidade de ambas as marcas serem oriundas da área de Cardais e não de Seilium, tendo em conta a ausência de registo de proveniência, não afecta a interpretação das siglas e do seu significado, já que, na época romana, era habitual (e desejável) a localização das instalações de fabrico de cerâmica de construção fora da cidade e nas proximidades dos barreiros. (Fernandes \& Ferreira, 2002, p. 261)

No entanto, tal como já tivemos a oportunidade de demonstrar, os achados arqueológicos que se sucederam nos anos seguintes revelam a existência de fornos cerâmicos junto à Igreja de Santa Maria dos Olivais em Tomar, achados que complementam o raciocínio da investigação anterior. (Fernandes \& Ferreira, 2002)

Desta forma, as investigações mais recentes consolidam o trabalho de José Vieira Guimarães, que na obra THOMAR Sta. Iria (1927), situa Sellium romana em Tomar, assim como, relembra a lenda de Santa Iria através dos vários autores, a padroeira de Tomar que tinha como tio o abade Sélio, cuja grafia se aproxima de Sellium. Outra aproximação presente na mesma obra, refere-se a um documento de 1317, transcrito por Pedro Alvares Seco da Ordem de Cristo, com a seguinte informação: na dita çidade oouvera moesteiros dosffrades negrados de queffora obade don selho tyo de Santa Eyrea e que soyam chamar a santa Maria de Thomar santa Maria de selho. (Guimarães, 1927, p.107).

José Vieira Guimarães recorda igualmente uma descoberta na década de 80 do século XIX, realizada pelo proprietário José Pereira Prista enquanto fazia a plantação da vinha, perto do antigo ribeiro das Canas em Tomar e junto à estrada que segue para a Serra, que foi convidado a visitar onde encontra,

vasta área coberta de ruínas de construcções, mais ou menos salientes, vários lares, tijolos grandes e pequenos, candeias de barro, mós de moinhos de mão, algumas moedas romanas e principalmente muitas e grandes pedras, tendo um dos topos moldados, indicativos de terem servido em alta cornija (Guimarães, 1927, p. 50).

Sobre este mesmo tema, encontrámos aquele que é um achado inédito e de interesse para este artigo, tratando-se de um capítulo da autoria de José Vieira Guimarães com cerca de dez páginas, intitulado A "Sellium" dos romanos é hoje representada por Thomar e a via militar de "Scalabis" a "Aeminium" passava ali, extraído de um boletim da "Asociación Española para el Progreso de las Ciencias", referente à sessão de 27 de junho de 1923 que aconteceu em Salamanca. (Guimarães, 1924)

O segundo congresso misto, organizado pela Associação Portuguesa para o Progresso da Ciência e pela Associação Espanhola para o Progresso das Ciências, realiza-se em Salamanca entre os dias 24 e 29 de junho de 1923, e é presidido na sessão de abertura pelo rei de Espanha D. Afonso XIII (1886-1941), tendo particularmente várias intervenções nacionais no terceiro tomo, onde intervém o médico nabantino. (Guimarães, 1924; Morais, 2007)

$\mathrm{Na}$ intervenção do dia 27 de junho, José Vieira Guimarães apresenta-se como Médico, professor do Liceu Camões, sócio da Real Academia de História de Madrid e da Academia das Sciencias de Lisboa, etc., etc., inicia por justificar Não falo castelhano e tenho pena, elogiando Salamanca, a Roma la chica tal como menciona, dando lugar a memórias de visita às ruas, monumentos e encantos, abordando a história da terra, até que na mudança de discurso cita Garcia de Resende: Non pude mais escrever,/ Por nã teer mais descoberto.; apresenta: a minha comunicação, é: A Sellium dos romanos é hoje representada por Thomar e a via militar de Scalabis a Aeminium passava ali. (Guimarães, 1924, p.63)

José Vieira Guimarães identifica a presença romana em Tomar, categoriza Nabância como lenda, explica e localiza Seilium em Tomar:

Ptolomeu que sob o nome de Sellium a nomeia em sua Geografia, e o Itenerario Antonino que lhe assigna-la a situação. Assigna-lha entre Scalabis e Aeminium, na única via que ligava a provincia da Lusitania á Tarraconense. Diz ele que Sellium ficava a 32 milhas de Scalabis e a 44 de Aeminium. A sêr Scalabis Santarem e Aeminium Coimbra, como assente está serem pontos d'aquela via, basta a eles nos referirmos e termos portanto de vêr a correspondência de Sellium com essas ci- 
dades, para assim podermos identifica-la. De Thomar a Coimbra contavam-se 13 leguas, e sendo uma maiores e outra menores, podemos dár a cada uma, como media geral, 5 kilometros, o que nos dá para as 13 leguas, 65 kilometros ou 65: ooo metros, os quais divididos por 1481 metros que são atribuídos a cada milha, temos 44 milhas e mais uns 164 metros. Diferença mínima a que não se ligará importância e por este lado devemos aceitar a concordância de Sellium com Thomar. Agora vejamos a distancia de Scalabis a Sellium. D'aquela a esta eram 32 milhas que á razão dos 1481 metros, são 47:392 metros que diferenção 108 metros dos 47:50o das 9, 1/2 léguas que distanciam Santarem de Tomar. Tambem pouca diferença é a de 108 metros que encontramos. (Guimarães, 1924, pp. 63-64)

Da mesma forma, como viria a apresentar na obra Thomar Sta. Iria (1927), o autor menciona Ceice e os estudos de Onomatologia que comprovam que Sellium não originou palavra Ceice, no entanto, o artigo de Salamanca menciona o nome dos cientistas envolvidos: a Sr $r^{\underline{a}}$. D. Carolina Micaelis de Vasconcelos e o Srọ. Dr. José Joaquim Nunes. (Guimarães, 1924, p. 64)

No Congresso de Salamanca, José Vieira Guimarães refere igualmente a presença de inscrições romanas no castelo de Tomar, provenientes da povoação, assim como, menciona a via romana de Scalabis a Aeminium, que Hubner não aceitou n'essa direção, que passaria por Sellium. Apresenta sobre este assunto, a correspondência por carta que realiza com o Dr. Feio de Carvalho, onde demonstra a sua visão sobre a via militar romana de Sellium (Thomar) a Aeminium (Coimbra), questionando se se lembrava de encontrar pedaços de calçada romana "em sítios que foram cortados pela estrada n.. 51 , assim como, se considerava que estas calçadas tinha sido construídas segundo os princípios que os romanos empregavam. Em resposta a José Vieira Guimarães, o Dr. Feio de Carvalho esclarece ter vislumbrado pequenos troços de calçada em Espinhal, assim como, entre os lugares da Venda das Figueiras e Tojeira, por onde passa a E. N. 51; entre mais informação, José Vieira Guimarães considera a ajuda deste ilustre engenheiro bastante útil, pois considera como prova da existência da estrada que passava em Sellium na direção de Aeminium. (Guimarães, 1924, pp. 68-71)

\section{CONCLUSÃO}

De um modo geral, poder-se-á afirmar que os trabalhos de investigação desenvolvidos por José Vieira da Silva Guimarães foram de importância para o estudo da Arqueologia em Tomar e de utilidade para investigações futuras.

Com este artigo conseguimos percorrer décadas de estudos arqueológicos em Tomar, onde surgem nomes como Joaquim Possidónio da Silva e José Leite de Vasconcelos, onde é entendível a divergência de opinião deste último arqueólogo no que toca ao assunto da existência e localização de Nabância na região. José Vieira da Silva Guimarães assiste a décadas de achados em Tomar e à evolução arqueológica, manifesta ser um seguidor de José Leite de Vasconcelos, questionando a existência de Nabância e erguendo uma nova visão, participa nas sociedades e associações que erguem a ciência.

Nesta contenda, é de assinalar a mudança de opinião de José Vieira Guimarães no que toca ao assunto relacionado com a presença romana em Tomar, considerando que no catálogo publicado em 1895 identifica Nabância romana na região, seguindo a linha de pensamento de Joaquim Possidónio da Silva e as publicações de António da Silva Magalhães, assim como, dos redatores do jornal A Verdade. Após a nova visão apresentada por José Leite de Vasconcelos em 1914, onde este coloca em causa a localização de Nabância defendida por Possidónio da Silva, José Vieira Guimarães questiona inclusive sobre a sua existência e aprofunda conhecimentos acerca do tema da lenda de Santa Iria. A presença do arqueólogo José Leite de Vasconcelos parece ser decisiva para o desencadear de acontecimentos que culminam na publicação da obra Thomar Sta. Iria em 1927.

A participação de José Vieira Guimarães em congressos é uma constante ao longo da sua vida, sendo que este artigo desvenda a participação deste nabantino em mais um, o congresso misto de Salamanca em 1923, onde defende a sua visão de localizar Seilium em Tomar, onde passaria a via romana entre Scalabis a Aeminium.

A descoberta do capítulo da intervenção de José Vieira Guimarães numa livraria de Madrid, permite perceber que a defesa desta visão acontece quatro anos antes da publicação da obra Thomar Sta. Iria, minuciosamente preparada, mas, no entanto, contestada. Sendo que consideramos, que a principal prova ficou por mostrar pelo médico nabantino, 
quando ignorou o conteúdo de uma estela encontrada na Galiza de um seiliense, que levou à localização de uma imaginária Seilensis no local galego, quando na realidade a inscrição revela o mesmo indivíduo que é mencionado numa outra estela romana presente na Torre de Menagem do Castelo de Tomar, tratando-se de um natural de terras nabantinas. Esta descoberta, em nossa análise, seria a prova que faltava a José Vieira Guimarães para sustentar com maior solidez a sua teoria.

Este artigo tem na sua base as gentes e o território que contam parte dos acontecimentos da Arqueologia em Tomar, onde José Vieira da Silva Guimarães é um elemento de relevo em prol da evolução do conhecimento científico. Desta forma, consideramos que através da pessoa que é este nabantino, em muito contribuímos para o estudo da Arqueologia em Tomar, com conteúdo que enriquece o entendimento da temática Nabância, assim como, na construção de conhecimento sobre o estudo de Seilium.

\section{FONTES}

Arquivo Nacional Torre do Tombo (2020) - Convento de Santa Iria de Tomar. Acedido em 12 de julho de 2020, em: https://digitarq.arquivos.pt/details?id=1379990

Direção Geral do Património Cultural (2020) - Acedido em 12 de julho de 2020, em: http://www.patrimoniocultural. gov.pt/en/patrimonio/patrimonio-imovel/pesquisa-do-patrimonio/classificado-ou-em-vias-de-classificacao/ geral/view/70607

\section{BIBLIOGRAFIA}

BATATA, C.; MOREIRA, B.; PONTE, S.; SILVA, V. (1983) Catálogo Tomar na arte antiga: exposição 1 a 20 de Março de 1983 integrado nas comemorações do Dia da Cidade. Tomar: Câmara Municipal de Tomar.

BATATA, Carlos (1997) - As origens de Tomar: a carta arqueológica do concelho. Tomar: Centro de Estudos e Protecção do Património da Região de Tomar.

C.M.T. - Câmara Municipal de Tomar (2020) - União das Freguesias de Tomar. Acedido em 12 de julho de 2020, em: http://www.cm-tomar.pt/index.php/pt/juntas-freguesia?start=10\#santa-maria-dos-olivais

CARVALHO, António; RAPOSO, Luís (2015) - José Leite de Vasconcelos: peregrino do saber. Lisboa: Museu Nacional de Arqueologia/Imprensa Nacional-Casa da Moeda.

CASTILLO, A; D’Ors, A. (1959) - Inscripciones romana de Galicia. Cuadernos de Estudios Gallegos 14. Corunha: Instituto Padre Sarmiento de Estudios Gallegos.
CENTRO DE ESTUDIOS HISTÓRICOS (1959) - Emérita. Madrid: Centro Estudios Históricos.

CORDEIRO, Luciano (1895) - Inscripções Portuguezas. Lisboa: Imprensa Nacional.

COSTA, António Carvalho da (1712) - Corografia portuguesa, e descripçam topografica do famoso reyno de Portugal: Tomo III. Lisboa: Oficina Real Deslandesiana.

Convento de Cristo (2020) - Igreja de Santa Maria do Olival. Acedido em 12 de julho de 202O, em: http://www.conventocristo.gov.pt/pt/index.php?s=white\&pid=237\&iden tificador=ct161_pt

CUSTÓDIO, Jorge (2008) - Renascença Artística e Práticas de Conservação e Restauro Arquitetónico em Portugal, durante a $1^{\underline{a}}$ República. Volume 1 . Tese de doutoramento apresentadas à Universidade de Évora.

Direção Geral do Património Cultural (2020) - Igreja de Santa Maria do Olival, compreendendo os túmulos, designadamente odeD.Diogo Pinheiro, 1.․․ bispo do Funchal. Acedido em 11 de julho de 2020, em: http://www.patrimoniocultural. gov.pt/pt/patrimonio/patrimonio-imovel/pesquisa-do-patrimonio/classificado-ou-em-vias-de-classificacao/ geral/view/70610

FERNANDES, Luís da Silva; FERREIRA, Rui (2002) - Marcas de oficina em tijolos romanos de Seilium. Conimbriga. Coimbra. 41, 257-267.

GARCÍA BAYÓN, Carlos (1997) - Piedras ilustres de la Barbanza, Muros y Xallas. Galiza: Editorial Diputación Provincial.

GUIMARÃES, José Vieira da Silva (1895) - Catálogo da Exposição Industrial-Agrícola de Thomar. Lisboa: Imprensa Lucas.

GUIMARÃES, José Vieira (1924) - A “Sellium” dos romanos é hoje representada por thomar e a via militar de "Scalabis" a "Aeminium" passava ali. Boletín de la "Asociación Española para el Progreso de las Ciencias". Madrid. Congresso de Salamanca, sessão de 27 de junho de 1923. Tomo VIII, pp. 61-71.

GUIMARÃES, José Vieira da Silva (1927) - Thomar Sta. Iria. Lisboa: Livraria Coelho.

MAGALHÃES, António da Silva (1893, 15 de outubro) Ruinas da Nabancia. A Verdade, pp. 2-3.

MAGALHÃES, António da Silva (1895, 14 de abril) - Última hora. A Verdade, p. 3.

MAGALHÃES, António da Silva (1895a, 21 de abril) - Centenário de Gualdim Paes. A Verdade, p. 2.

MARTINS, Ana Cristina (2003) - Possidónio da Siva (18061896) e o elogio da memória. Um percurso na arqueologia de Oitocentos. Lisboa: AAP. 
MARTINS, Ana Cristina (2012-2013) - Entre a metamorfose e a adaptação de associação dos arquitectos civis portugueses a real associação dos arquitectos civis e arqueólogos portugueses (1863-1896). Arqueologia e História. Lisboa. Vol. 64-65: 15-29.

MARTINS, Ana Cristina (2015) - A Associação dos Arqueólogos Portugueses na senda da salvaguarda patrimonial. 100 anos de transformação (1863-1963). 2 vols. [Texto policopiado]. Tese de Doutoramento em História (História da Arte) apresentada à Universidade de Lisboa.

MARTINS, Ana Cristina (2016) - Francisco Tavares Proença Júnior (1883-1916) e arqueologia em Castelo Branco na viragem para o século XX: textos, contextos e (des)venturas. II Congresso Internacional de Arqueologia da Região de Castelo Branco. Castelo Branco. pp. 25-6o.

MARTINS, Ana Cristina (2017) - A Real Associação dos Arquitectos Civis e Arqueólogos Portugueses e o Museu Arqueológico do Carmo: alguns percursos internacionais (abordagem preliminar). Boletim da Academia Internacional da Cultura Portuguesa. Lisboa. pp. 99-131.

MARIOTTO, Elisabeta (2020) - José Leite de Vasconcelos. Acedido em 12 de julho de 2020, em: http://cvc.instituto-camoes.pt/seculo-xix/jose-leite-de-vasconcelos.html\#. XwtvGyhKiUk

MORAIS, Marta (2007) - A primeira década dos congressos luso-espanhóis para o progresso das ciências. Aveiro: Universidade de Aveiro.

Museu Centro de Artes Figueiró dos Vinhos (2020) - Biografia de Manuel Henrique Pinto. Acedido em 11 de julho de 2020, em: https://www.mcafigueirodosvinhos.pt/ index.php/2013-04-08-14-35-07/os-nossos-artistas/8-noticias/47-biografia-de-manuel-henrique-pinto

Património Galego (2012) - Lauda Romana de Queiruga. Acedido em 12 de julho de 2020, em: http://patrimoniogalego.net/index.php/23441/2012/o8/lauda-romana-dequeiruga/

PEIXOTO, João Amendoeira (2019) - Vieira Guimarães e o Património Cultural de Tomar: primeira abordagem. Tomar: Gualdim Edições.

PEIXOTO, João Amendoeira (2020) - Thomar Pietra: segredo de pedra. Tomar: Gualdim Edições.

PEIXOTO, João Amendoeira (2O2Oa, 14 de fevereiro) - Sabinula e o seu filho Caius. Jornal Cidade de Tomar, p. 30.

PIETRA, Pedro de Roure (1863, 28 de fevereiro) - Gualdim Paes. Gazeta de Portugal, p. 1.

Portal do Arqueólogo (2020). Tomar/Sellium - Cerrado de João do Couto. [Consult. 22 de novembro de 2019] Disponível em: http://arqueologia.patrimoniocultural.pt/index.php?sid $=$ sitios\&subsid $=54066$
Portal do Arqueólogo (2020a) - Escavação 2008/2009. [Consult. 22 de novembro de 2019] Disponível em: https:// arqueologia.patrimoniocultural.pt/index.php?sid=trabalho s\&subsid=3170224

PONTE, Salete da (1994) - J.L. Vasconcelos e os percursos por Tomar antiga. O Arqueólogo Português, Série IV. 11-12: 135-141.

SILVA, Pedro Corrêa da (1895, 13 de outubro) - D. Gualdim Paes. Diario Illustrado, p. 1.

SILVA, Joaquim Possidónio da (1881) - Descobrimento da Cidade Romana «Nabancia» em Portugal. Boletim da Real Associação dos Architectos Civis e Archeologos Portuguezes. Lisboa. Tomo III. 10: 152-154.

VASCONCELOS, José Leite (1895) - Antiguidades romanas de Tomar. O Archeologo Português. 1: 13-15.

VASCONCELOS, José Leite (1914) - Antiguidades de Tomar. O Archeologo Português. 19: 146-151.

VASCONCELOS, José Leite (1914a) - Inscrição romana de Lorvão. O Archeologo Português. 19: 365-366.

VENTURA, António (2004) - António da Silva Magalhães Photographo de Thomar. Tomar: Câmara Municipal de Tomar. 


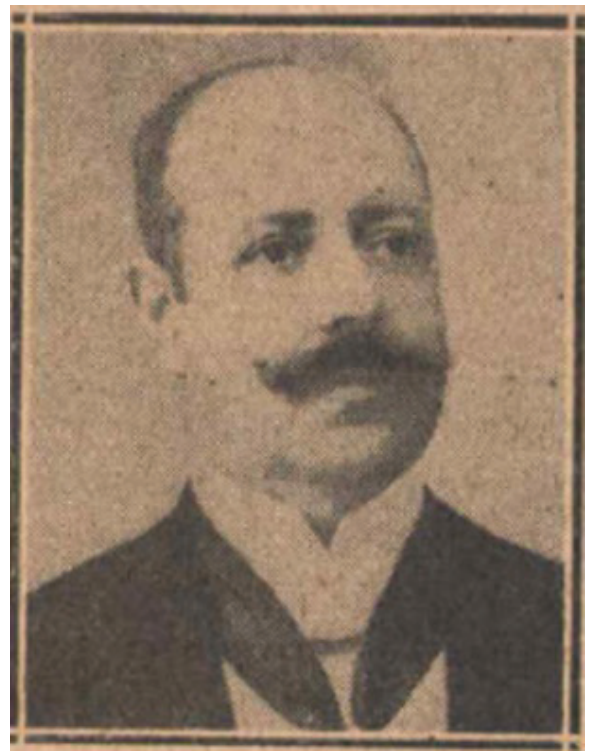

Figura 1 - José Vieira da Silva Guimarães.

\section{A' altima bora}

1) - prequizas n que procederam ta eggresju do Sunita Mario dus Olivace, un nossos minizos on kl's. Munoel Hientique Pinto o Juné Vieiri da Silva Guimurane, foit encontrerta a cuthina e resprectivo opitnphio do D. Gualditic Pnon, os qunes bu nututo se connidorhram perdidos ou nnutiquillados.

No proximo numiero nos roferirombs tom mais vingar a obto sosumpto.

Figura 2 - Notícia do jornal A Verdade, edição №781. (Magalhães, 1895).

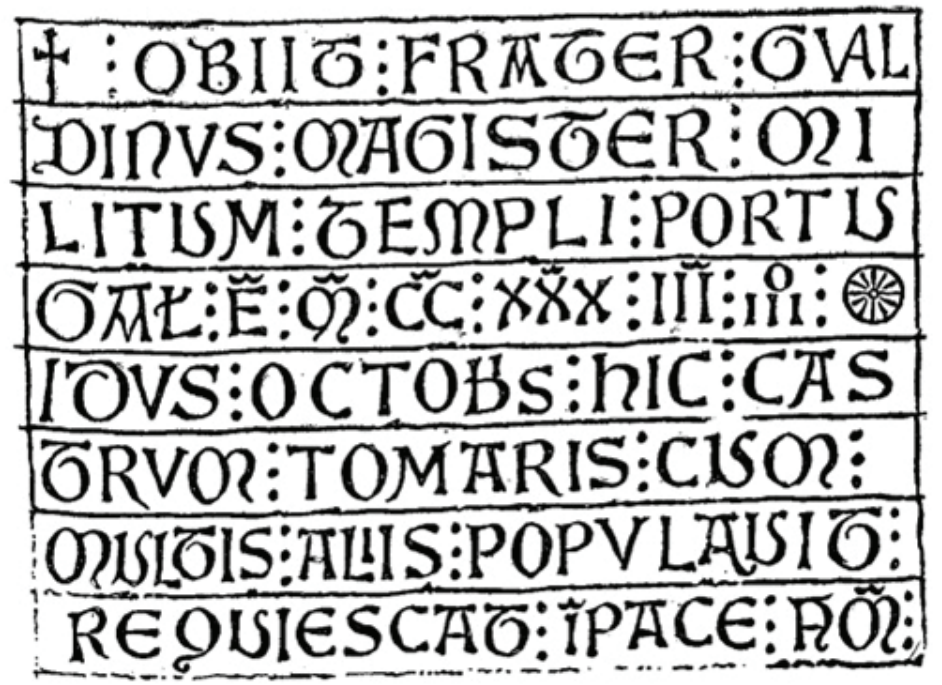

Figura 3 - Ilustração presente na obra de Luciano Cordeiro (1895), com possibilidade de ser da autoria de Manuel Henrique Pinto (Cordeiro, 1895, p. 46). 

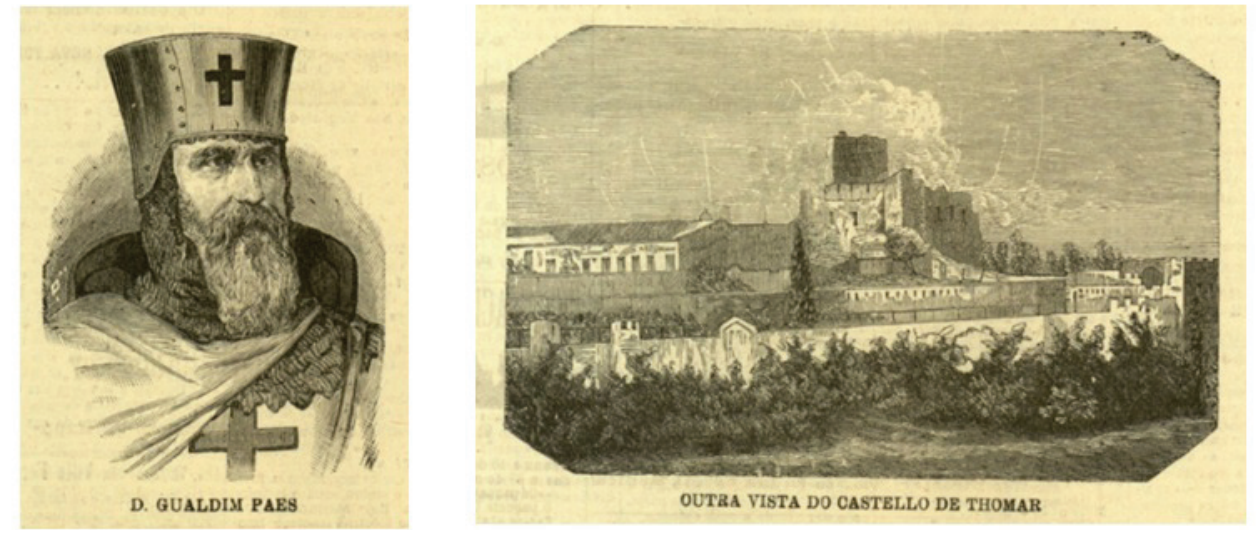

Figura 4 - Ilustrações do Diario Illustrado (Silva, 1895).

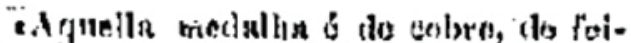

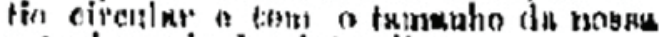
aofinal mortia de vinte rós:

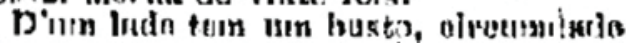

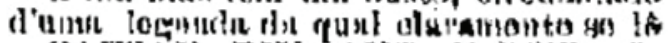

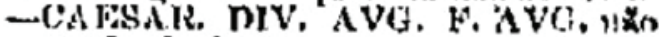

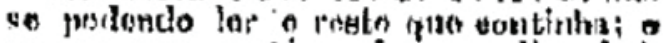
to revorso, contern a insegem d'uen losl,

tendo. is sun parte ouperior a palavtu MVNI(JIP. a ma interior... BAEN'VAI, reconhecondo-se por uns pequenissionos

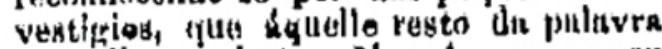
yrecudian so lettris N. e $A_{\text {, }}$ que no rou

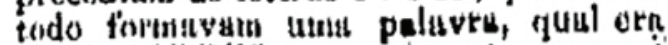
NABALN'IVM,

$-$

Figura 5 - Extrato do jornal A Verdade, no 703 de 15 de outubro, que comprova a leitura, por parte da imprensa local, da palavra "NABAENTVM".

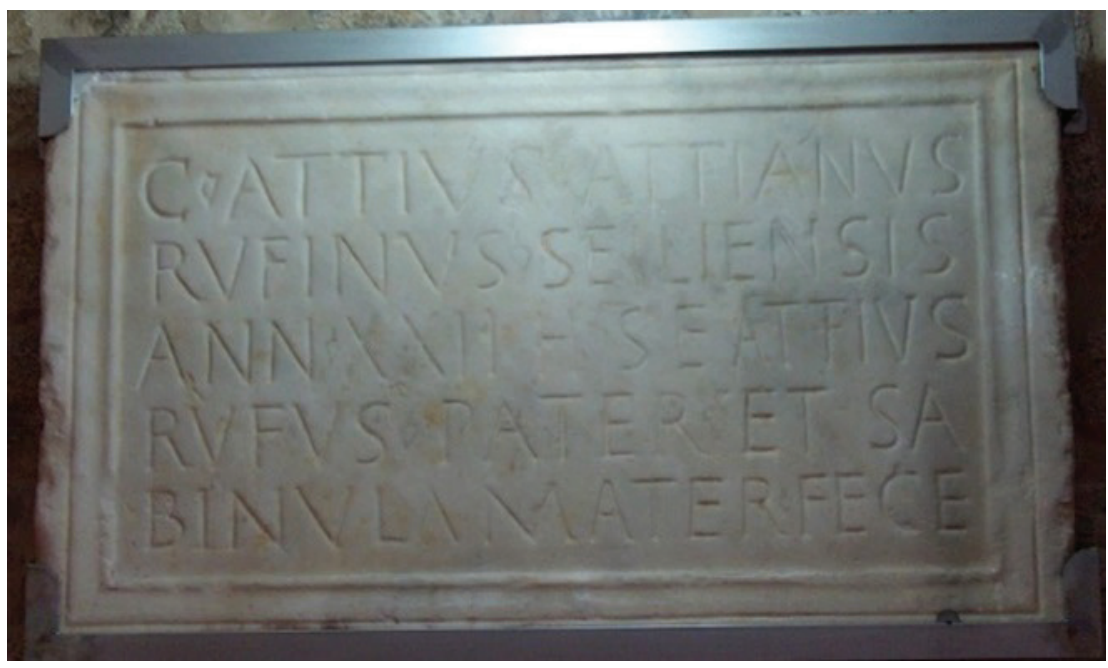

Figura 6 - Estela romana em Queiruga, Galiza. (Património Galego, 2020) 



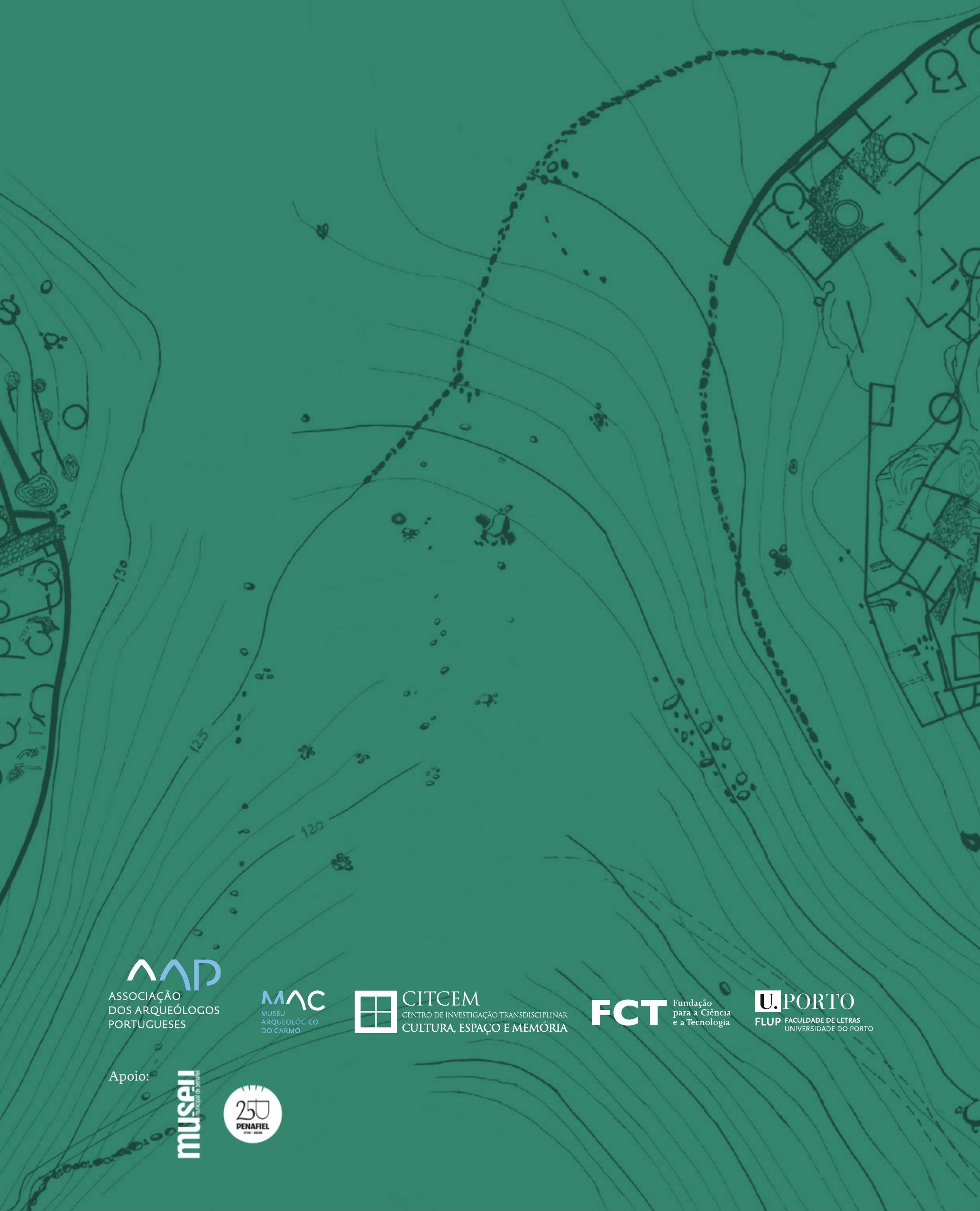

